Prepared in cooperation with the Muskingum Watershed Conservancy District and Richland County

\title{
Hydrologic and Hydraulic Analyses of Selected Streams in Richland County, Ohio
}

Scientific Investigations Report-2019-5011 
Cover. View looking upstream at the spillway of the Clear Fork Reservoir for Clear Fork Mohican River near Lexington, Ohio. Photograph by U.S. Geological Survey, April 2015. 


\section{Hydrologic and Hydraulic Analyses of Selected Streams in Richland County, Ohio}

By Chad J. Ostheimer

Prepared in cooperation with the Muskingum Watershed Conservancy District and Richland County

Scientific Investigations Report 2019-5011 


\title{
U.S. Department of the Interior \\ DAVID BERNHARDT, Secretary
}

\author{
U.S. Geological Survey \\ James F. Reilly II, Director
}

U.S. Geological Survey, Reston, Virginia: 2019

For more information on the USGS - the Federal source for science about the Earth, its natural and living resources, natural hazards, and the environment-visit https://www.usgs.gov or call 1-888-ASK-USGS.

For an overview of USGS information products, including maps, imagery, and publications,

visit https://store.usgs.gov.

Any use of trade, firm, or product names is for descriptive purposes only and does not imply endorsement by the U.S. Government.

Although this information product, for the most part, is in the public domain, it also may contain copyrighted materials as noted in the text. Permission to reproduce copyrighted items must be secured from the copyright owner.

Suggested citation:

Ostheimer, C.J., 2019, Hydrologic and hydraulic analyses of selected streams in Richland County, Ohio: U.S. Geological Survey Scientific Investigations Report 2019-5011, 18 p., https://doi.org/10.3133/sir20195011.

ISSN 2328-0328 (online) 


\section{Contents}

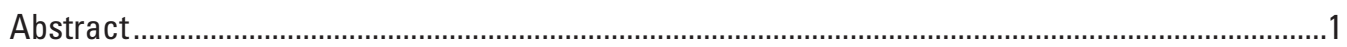

Introduction

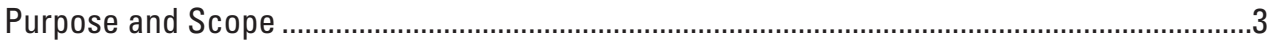

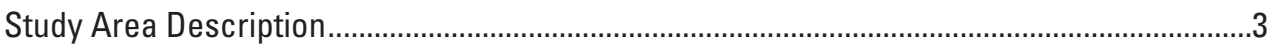

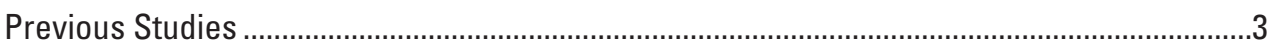

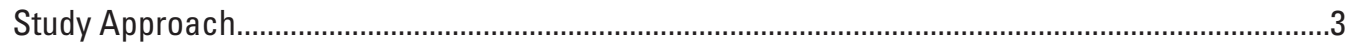

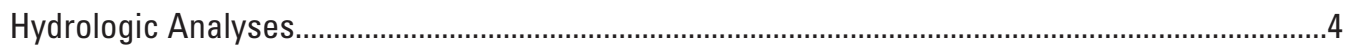

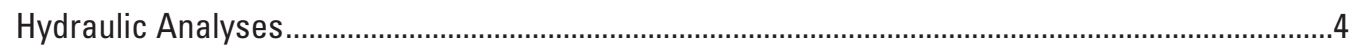

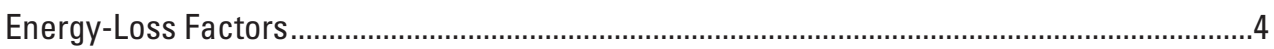

Field Surveys

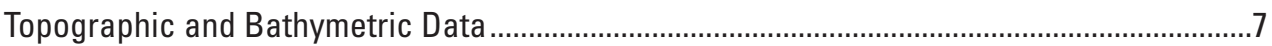

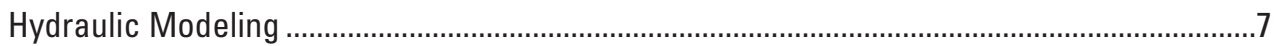

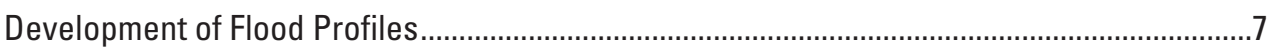

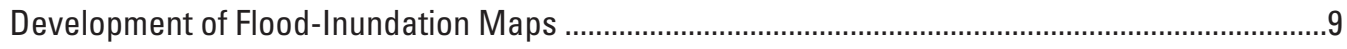

Disclaimer for Flood-Inundation Maps ................................................................................

Uncertainties and Limitations Regarding Use of Flood-Inundation ........................................9

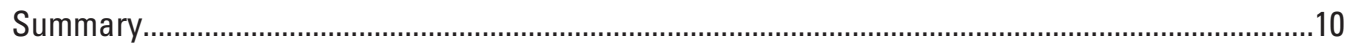

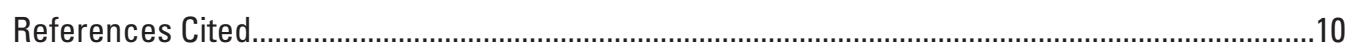

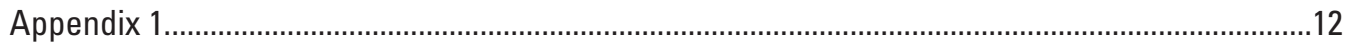

Appendix 2

\section{Figures}

1. Map showing location of study reaches for the Clear Fork Mohican River and Cedar Fork, Ohio, and locations of U.S. Geological Survey streamgages ........................2

1.1. Graphs showing computed water-surface profiles for flood events with annual exceedance probabilities of 10-, 4-, 2-, 1-, and 0.2-percent and 1-percent plus for the Clear Fork Mohican River, Richland County, Ohio

1.2. Graphs showing computed water-surface profiles for flood events with annual exceedance probabilities of 10-, 4-, 2-, 1-, and 0.2-percent and 1-percent plus for the Cedar Fork, Richland County, Ohio

2.1. Map showing flood inundation areas for the 1- and 0.2-percent annual exceedance probability floods and a regulatory floodway along the Clear Fork Mohican River, Richland County, Ohio

2.2. Map showing flood inundation areas for the 1- and 0.2-percent annual exceedance probability floods and a regulatory floodway along the Cedar Fork, Richland County, Ohio 


\section{Tables}

1. U.S. Geological Survey gaging information for Clear Fork Mohican River and Cedar Fork within Richland County, Ohio.

2. Summary of the explanatory variable values used in the regression equations and the initial 10-, 4-, 2-, 1-, and 0.2-percent and 1-percent plus ${ }^{1}$ annual exceedance probability flood-peak streamflow estimates and locations for the selected streams in Richland County, Ohio.

3. Peak-flood estimates for the 10-, 4-, 2-, 1-, and 0.2-percent annual exceedance probability floods are reported in Koltun and others (2006), and weighting ratio equal to the weighted regression estimate divided by the regression estimate

4. Summary of the final 10-, 4-, 2-, 1-, and 0.2-percent and 1-percent plus annual exceedance probability flood-peak streamflow estimates and locations for the selected streams in Richland County, Ohio.

5. Selected hydraulic parameters used in the hydraulic models .6

6. Calibration results of the Clear Fork Mohican River hydraulic model to recorded water-surface elevations for 16 flood events.

7. Results of the Clear Fork Mohican River overflow analysis.

\section{Conversion Factors}

U.S. customary units to International System of Units

\begin{tabular}{|c|c|c|}
\hline Multiply & By & To obtain \\
\hline \multicolumn{3}{|c|}{ Length } \\
\hline foot $(\mathrm{ft})$ & 0.3048 & meter $(\mathrm{m})$ \\
\hline mile (mi) & 1.609 & kilometer $(\mathrm{km})$ \\
\hline \multicolumn{3}{|c|}{ Area } \\
\hline square mile $\left(\mathrm{mi}^{2}\right)$ & 2.590 & square kilometer $\left(\mathrm{km}^{2}\right)$ \\
\hline \multicolumn{3}{|c|}{ Flow rate } \\
\hline cubic foot per second $\left(\mathrm{ft}^{3} / \mathrm{s}\right)$ & 0.02832 & cubic meter per second $\left(\mathrm{m}^{3} / \mathrm{s}\right)$ \\
\hline
\end{tabular}

\section{Datum}

Vertical coordinate information is referenced to (1) stage, the height above an arbitrary datum established at a streamgage and (2) elevation, the height above the North American Vertical Datum of 1988 (NAVD 88).

Horizontal coordinate information is referenced to the North American Datum of 1983 (NAD 83). 


\title{
Hydrologic and Hydraulic Analyses of Selected Streams in Richland County, Ohio
}

\author{
By Chad J. Ostheimer
}

\section{Abstract}

Hydrologic and hydraulic analyses were done for selected reaches of Clear Fork Mohican River and Cedar Fork in Richland County, Ohio. To update and expand a portion of the Federal Emergency Management Agency detailed Flood Insurance Study, the U.S. Geological Survey (USGS) and the Muskingum Watershed Conservancy District initiated a cooperative study. The study comprised an 18.6-mile reach of the Clear Fork Mohican River and a 5.9-mile reach of Cedar Fork.

Historical streamflow data from the streamgage Clear Fork Mohican River at Bellville, Ohio (USGS station number 03131982) and regional regression equations were used to estimate instantaneous peak streamflows for floods with 10-, 4-, 2-, 1-, and 0.2-percent and 1-percent plus annual exceedance probabilities. The 1-percent plus flood elevation is defined by the Federal Emergency Management Agency as a flood elevation derived by using streamflows that include the average predictive error for the regression equation streamflow calculation for the Flood Risk project. This error is then added to the 1-percent annual exceedance probability flood streamflow to calculate the new 1-percent plus streamflow.

The annual exceedance probability streamflows were then used in a Hydrologic Engineering Center-River Analysis System step-backwater model to determine water-surface elevation profiles and flood-inundation boundaries for the 10-, 4-, 2-, 1-, and 0.2-percent and 1-percent plus annual exceedance probability floods and a regulatory floodway along a selected reach of each stream. The Clear Fork Mohican River model was calibrated to 16 flood events by using the current stage-streamflow relation at the streamgage Clear Fork Mohican River at Bellville, Ohio (USGS station number 03131982) and a submersible pressure transducer. Flood-inundation boundaries for the 1- and 0.2-percent annual exceedance probability floods and a regulatory floodway were mapped for each stream.

\section{Introduction}

Major flooding happened along the Clear Fork Mohican River (fig. 1) in 1959 and 1987. During the 1959 flood, Bellville, Ohio, (fig. 1) was completely isolated for a time (Cross and Brooks, 1959). The July 1987 flood event had a peak-flood stage of approximately 16.8 feet (ft) at the Main Street bridge in Bellville (Mayo and Mangus, 1989). For reference, major flood stage for Bellville as designated by the National Weather Service (NWS) is $15.5 \mathrm{ft}$ (National Weather Service, 2018). Damages in Bellville from the July 1987 flood event were estimated to be more than $\$ 5$ million (Mayo and Mangus, 1989).

Prior to this study, officials and emergency responders relied on several information sources to make decisions on how to best alert the public and mitigate flood damages. One source of information is the Federal Emergency Management Agency (FEMA) Flood Insurance Study (FIS) for Richland County, Ohio (fig. 1), dated April 4, 2011 (Federal Emergency Management Agency, 2011). A second source of information is the U.S. Geological Survey (USGS) streamgages and lake-level gages (table 1) from which current (U.S. Geological Survey, 2017a, b, c) and historical (U.S. Geological Survey, 2017d) stages and streamflows, including annual peak streamflows, can be obtained. A third source of flood-related information is the NWS Advanced Hydrologic Prediction Service (AHPS), which displays the USGS stage data from the streamgage Clear Fork Mohican River at Bellville, Ohio (USGS station number 03131982) and provides flood forecasts of stage for this AHPS site (BLEO1; National Weather Service, 2018).

Residential and commercial development has occurred in parts of Richland County, with more development expected in the future. Development in the upper basins of the study streams may result in increased flood-peak streamflows, potentially causing increased flood damage along the downstream reaches. Officials within Richland County are considering various options to mitigate downstream flood damage along the studied streams. 


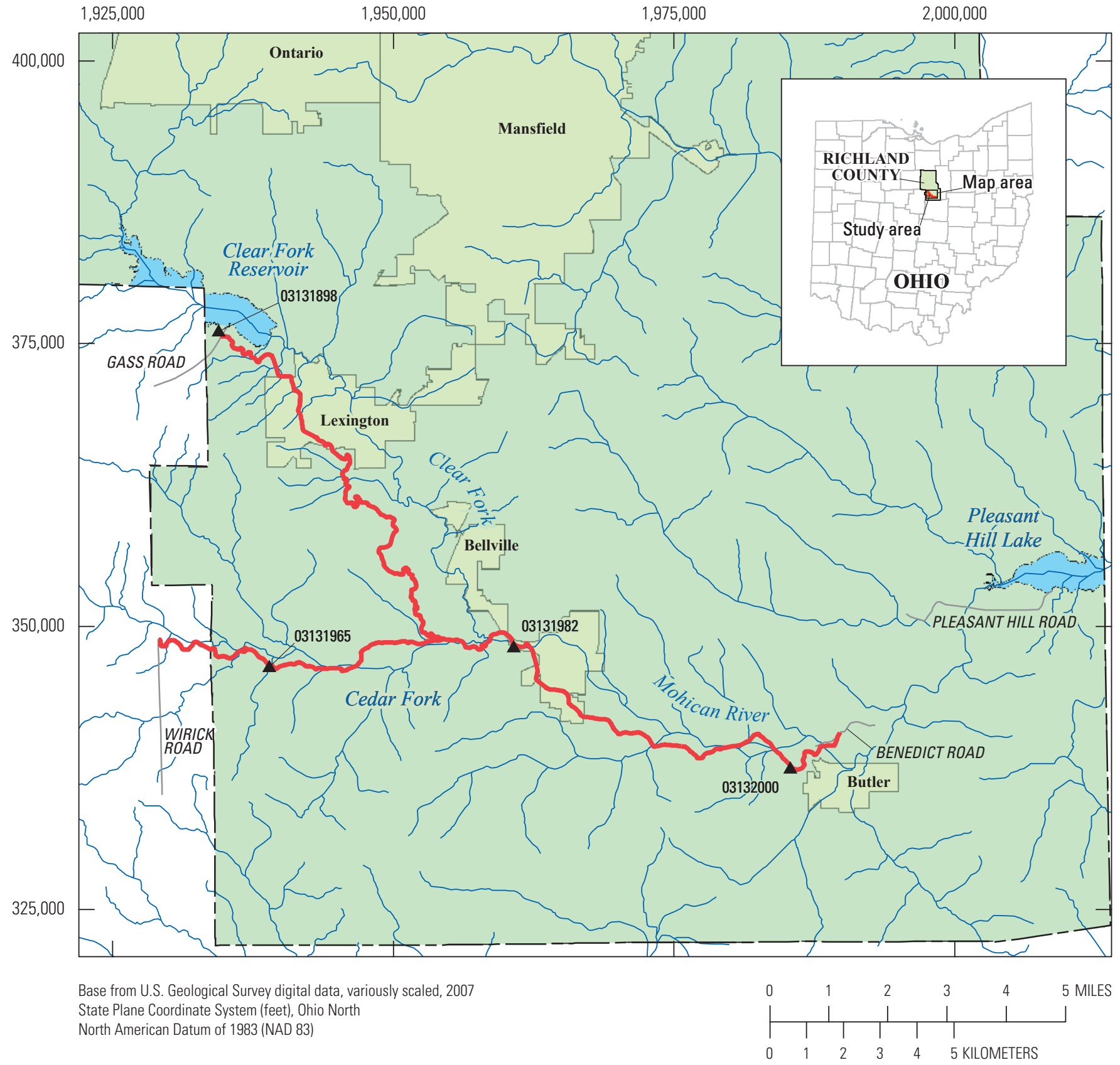

EXPLANATION

\begin{tabular}{|c|c|c|c|}
\hline & Municipal boundary & $\overline{-}$ & Selected road \\
\hline & Lake or reservoir & - & Study reach \\
\hline & Richland County & $\Delta^{03132000}$ & U.S. Geological Survey streamgage and station number \\
\hline
\end{tabular}

Figure 1. Location of study reaches for the Clear Fork Mohican River and Cedar Fork, Ohio, and locations of U.S. Geological Survey streamgages. 
Table 1. U.S. Geological Survey gaging information for Clear Fork Mohican River and Cedar Fork within Richland County, Ohio.

[Site locations are shown in figure 1. USGS, U.S. Geological Survey; ft, foot; NAVD 88, North American Vertical Datum of 1988; current, 2018]

\begin{tabular}{|c|c|c|c|c|c|c|}
\hline Site name & $\begin{array}{l}\text { USGS station } \\
\text { number }\end{array}$ & $\begin{array}{l}\text { Drainage area } \\
\text { (square miles) }\end{array}$ & Latitude & Longitude & $\begin{array}{l}\text { Period } \\
\text { of record }\end{array}$ & $\begin{array}{l}\text { Maximum state (ft) (elevation } \\
\text { [ft, NAVD 88]), date }\end{array}$ \\
\hline $\begin{array}{l}\text { Clear Fork Reservoir } \\
\text { near Lexington, Ohio }\end{array}$ & 03131898 & 33.7 & $40^{\circ} 41^{\prime} 59^{\prime \prime}$ & $82^{\circ} 36^{\prime} 22^{\prime \prime}$ & 2015 to current & 1,203.31(1,203.31), 01/12/2017 \\
\hline $\begin{array}{l}\text { Clear Fork Mohican River } \\
\text { at Bellville, Ohio }\end{array}$ & 03131982 & 115 & $40^{\circ} 37^{\prime} 24^{\prime \prime}$ & $82^{\circ} 30^{\prime} 40^{\prime \prime}$ & 2015 to current & $16.82(1,126.90), 7 / 1 / 1987$ \\
\hline Clear Fork at Butler, Ohio & 03132000 & 136 & $40^{\circ} 35^{\prime} 37^{\prime \prime}$ & $82^{\circ} 25^{\prime} 20^{\prime \prime}$ & 1945 to 1975 & $10.87(1,067.50), 7 / 2 / 1987$ \\
\hline $\begin{array}{l}\text { Cedar Fork above } \\
\text { Bellville, Ohio }\end{array}$ & 03131965 & 35.8 & $40^{\circ} 37^{\prime} 04^{\prime \prime}$ & $82^{\circ} 35^{\prime} 23^{\prime \prime}$ & 2017 to current & $10.55(1,164.88), 11 / 18 / 2017$ \\
\hline
\end{tabular}

\section{Purpose and Scope}

The purpose of this report is to describe the methods and results of hydrologic and hydraulic analyses for an 18.6-mile reach of Clear Fork Mohican River and a 5.9-mile reach of Cedar Fork in Richland County, Ohio (fig. 1). The analyses include (1) estimates of flood-peak streamflows corresponding to floods with annual exceedance probabilities (AEPs) of 10-, 4-, 2-, 1-, and 0.2-percent and 1-percent plus and (2) determination of water-surface elevation profiles and flood plain boundaries associated with the AEPs and a regulatory floodway. A "regulatory floodway" means the channel of a river or other watercourse and the adjacent land areas that must be reserved to discharge the base flood without cumulatively increasing the water-surface elevation more than a designated height (Federal Emergency Management Agency, 2018).

\section{Study Area Description}

Richland County is in north-central Ohio (fig. 1) with an estimated population of about 124,500 (U.S. Census Bureau, 2010). Clear Fork Mohican River flows southwest from its headwaters near Ontario, Ohio, before turning southeast and passing through the villages of Lexington, Bellville, and Butler (fig. 1). Cedar Fork enters southwest Richland County from the west and joins with Clear Fork Mohican River just upstream from the village of Bellville. The drainage area of Clear Fork Mohican River is predominantly rural with some isolated pockets of development, whereas the Cedar Fork drainage is entirely rural. Immediately upstream from Lexington, the city of Mansfield has a water-supply reservoir (Clear Fork Reservoir) on the Clear Fork Mohican River (fig. 1). The reservoir water level is passively controlled by the fixed-elevation outflow weir and, therefore, does not provide meaningful flood protection (Federal Emergency Management Agency, 2011).

\section{Previous Studies}

The effective FEMA FIS for Richland County was published on April 4, 2011 (Federal Emergency Management Agency, 2011). In the FIS, portions of the Clear Fork Mohican River study reach were studied by detailed methods in 1988 and 1991 using hydrology completed in 1965. Cedar Fork was studied by approximate methods and no hydrology was provided. Flood-inundation areas were re-delineated using light detection and ranging (lidar) data collected in 2005 by the Richland County Regional Planning Commission (2018).

\section{Study Approach}

Tasks specific to development of the flood maps were (1) collection of topographic and bathymetric data for selected cross sections and geometric data for structures and bridges along the study reach, (2) estimation of peakflood streamflows using regional regression equations and streamgage data where available, (3) estimation of energyloss factors (roughness coefficients) in the stream channel and flood plain, (4) computation of flood profiles (including a regulatory floodway) by using the U.S. Army Corps of Engineers' Hydrologic Engineering Center-River Analysis System (HEC-RAS) computer program (U.S. Army Corps of Engineers, 2010), and (5) production of flood-inundation maps at various stream stages by using the U.S. Army Corps of Engineers' Hydrologic Engineering Center-GeoRiver Analysis System (HEC-GeoRAS) computer program (U.S. Army Corps of Engineers, 2009) and Geographic Information System (GIS). HEC-GeoRAS is a set of procedures, tools, and utilities for processing geospatial data in ArcGIS. The hydraulic model was calibrated to 16 flood events. The flood profiles and the regulatory floodway have been submitted to FEMA and are being used to update the FIS. 


\section{Hydrologic Analyses}

The study reaches contain three streamgages and one lake-level gage. The lake-level gage (Clear Fork Reservoir near Lexington, Ohio, USGS station number 03131898) only collects stage data (streamflow is not computed). The streamgages Clear Fork Mohican River at Bellville, Ohio (USGS station number 03131982, established in 2015, hereafter referred to as the Bellville streamgage) and Cedar Fork above Bellville, Ohio (USGS station number 03131965, established in 2017) did not have sufficient historical streamflow data (generally 10 years) to calculate the flood-peak streamflows using observed streamflow data (Interagency Committee on Water Data, 1982). The Butler streamgage has 31 years of data, and the data were used to estimate the 10-, 4-, 2-, 1-, and 0.2-percent and 1-percent plus AEP streamflows for Clear Fork Mohican River (Interagency Committee on Water Data, 1982).

Initially, regional regression equations were used to estimate the AEP flood-peak streamflows for selected locations on Clear Fork Mohican River and Cedar Fork using the Ohio StreamStats application (Koltun and others, 2006). The StreamStats application solves regional regression equations that use (1) drainage area, (2) main channel slope (determined by the 10-85 method, SL10-85), and (3) storage (percentage of drainage classified as water and wetlands area) as explanatory variables. The explanatory variables are computed within StreamStats on the basis of geospatial datasets. StreamStats estimates are based on the assumption that the basin is not appreciably regulated and is without significant urbanization (Koltun and others, 2006). The resulting initial flood-peak streamflow estimates are listed in table 2 .

For Clear Fork Mohican River, the initial regression estimates were adjusted to consider data from the Butler streamgage. The adjustment applied to each AEP peak-flood streamflow estimate was a ratio equal to the weighted regression estimates divided by the Log Pearson type III regression estimates (Interagency Committee on Water Data, 1982) for the Clear Fork at Butler, Ohio, streamgage (USGS station number 03132000) provided in Koltun and others (2006) (table 3). The initial regression estimates for each annual exceedance probability peak-flood streamflow estimate were then multiplied by their respective ratio to produce the final adjusted peak-flood estimates provided in table 4 . For the 1-percent plus AEP flood event, the ratio was assumed to be the same as the 1-percent AEP flood event. For Cedar Fork, no streamgage data were available; therefore, the initial regression estimates were used as the final values.

\section{Hydraulic Analyses}

The flood profiles used to develop the flood-inundation maps for this study were computed by use of HEC-RAS, version 4.1.0 (U.S. Army Corps of Engineers, 2010). HEC-RAS is a one-dimensional step-backwater model for determining flood profiles under steady-state or unsteady-state flow conditions. All profiles developed for this report were run within HEC-RAS using the steady-state flow condition. Steady-state flow data consisted of flow regime, boundary conditions, and streamflow estimates. Subcritical flow regime was assumed for all simulations.

\section{Energy-Loss Factors}

Hydraulic analyses require the estimation of energy losses exerted by a channel on flow. These energy losses are quantified by the Manning's roughness coefficient (" $n$ " value). Initial (precalibration) $n$ values were selected on the basis of field observations and high-resolution aerial photographs. As part of the calibration process, initial $n$ values were adjusted until the differences between simulated and rated water-surface elevations at the Bellville streamgage and at a submersible pressure transducer near the downstream corporate limits for Bellville were minimized. For Clear Fork Mohican River, the final $n$ values ranged from 0.036 to 0.044 for the main channel and from 0.030 to 0.100 for the overbank areas (table 5). For Cedar Fork, the final $n$ values ranged from 0.040 to 0.046 for the main channel and from 0.020 to 0.100 for the overbank areas (table 5).

\section{Field Surveys}

The USGS used the differential global positioning system (GPS) and differential-leveling surveys (hereafter referred to as conventional surveys) for this study. The differential GPS surveys established a control network at pertinent locations along each of the streams studied. Conventional surveys were done to obtain stream and hydraulic-structure geometry. All conventional survey data collected met third-order accuracy (horizontal and vertical) criteria (Federal Geodetic Control Committee, 1984). Differential GPS surveys were led by the USGS using Real-Time Network surveying techniques (Rydlund and Densmore, 2012). Elevations determined by using differential GPS at 11 benchmark locations had a root-meansquare error of $0.09 \mathrm{ft}$ compared to National Geodetic Survey published elevations. 
Table 2. Summary of the explanatory variable values used in the regression equations and the initial 10-, 4-, 2-, 1-, and 0.2-percent and 1-percent plus ${ }^{1}$ annual exceedance probability flood-peak streamflow estimates and locations for the selected streams in Richland County, Ohio.

[ft $3 / \mathrm{s}$, cubic foot per second; \%, percent; DS, downstream; US, upstream]

\begin{tabular}{|c|c|c|c|c|c|c|c|c|c|c|c|}
\hline \multirow[t]{2}{*}{ Location description } & \multirow[t]{2}{*}{ Latitude } & \multirow[t]{2}{*}{ Longitude } & \multirow{2}{*}{$\begin{array}{l}\text { Drainage area } \\
\text { (square miles) }\end{array}$} & \multirow{2}{*}{$\begin{array}{l}\text { Main channel } \\
\text { slope }^{2} \\
\text { (foot per mile) }\end{array}$} & \multirow{2}{*}{$\begin{array}{c}\text { Storage } \\
\text { (water or wetlands } \\
\text { area), percent }\end{array}$} & \multicolumn{6}{|c|}{$\begin{array}{l}\text { Annual exceedance probability } \\
\text { flood-peak streamflows }{ }^{3}\left(\mathrm{ft}^{3} / \mathrm{s}\right)\end{array}$} \\
\hline & & & & & & $10 \%$ & $4 \%$ & $2 \%$ & $1 \%$ & $0.2 \%$ & $1 \%$ plus \\
\hline \multicolumn{12}{|c|}{ Clear Fork Mohican River } \\
\hline DS from Clear Fork Dam & $40^{\circ} 41^{\prime} 52^{\prime \prime}$ & $82^{\circ} 36^{\prime} 21^{\prime \prime}$ & 33.7 & 11.7 & 5.99 & 1,950 & 2,400 & 2,730 & 3,070 & 3,830 & 4,240 \\
\hline At Lexington Springmill Road & $40^{\circ} 41^{\prime} 16^{\prime \prime}$ & $82^{\circ} 35^{\prime} 08^{\prime \prime}$ & 45.3 & 11.7 & 4.93 & 2,540 & 3,140 & 3,580 & 4,030 & 5,040 & 5,560 \\
\hline At U.S. Route 42 & $40^{\circ} 40^{\prime} 43^{\prime \prime}$ & $82^{\circ} 34^{\prime} 48^{\prime \prime}$ & 51.4 & 10.9 & 4.41 & 2,820 & 3,490 & 3,980 & 4,480 & 5,600 & 6,180 \\
\hline At Interstate 71 & $40^{\circ} 38^{\prime} 26^{\prime \prime}$ & $82^{\circ} 32^{\prime} 59^{\prime \prime}$ & 62.0 & 8.35 & 4.13 & 3,140 & 3,860 & 4,390 & 4,930 & 6,140 & 6,800 \\
\hline US from Cedar Fork & $40^{\circ} 37^{\prime} 29^{\prime \prime}$ & $82^{\circ} 32^{\prime} 11^{\prime \prime}$ & 64.4 & 7.45 & 4.10 & 3,160 & 3,880 & 4,410 & 4,950 & 6,150 & 6,830 \\
\hline 1,300 feet DS from Hines Avenue & $40^{\circ} 37^{\prime} 01^{\prime \prime}$ & $82^{\circ} 30^{\prime} 15^{\prime \prime}$ & 116 & 7.20 & 2.52 & 5,400 & 6,660 & 7,600 & 8,560 & 10,700 & 11,800 \\
\hline US from Honey Creek & $40^{\circ} 36^{\prime} 05^{\prime \prime}$ & $82^{\circ} 28^{\prime} 39^{\prime \prime}$ & 118 & 7.08 & 2.36 & 5,470 & 6,730 & 7,680 & 8,650 & 10,800 & 11,900 \\
\hline US from Smoky Run & $40^{\circ} 35^{\prime} 34^{\prime \prime}$ & $82^{\circ} 25^{\prime} 10^{\prime \prime}$ & 136 & 7.24 & 2.26 & 6,230 & 7,680 & 8,770 & 9,880 & 12,400 & 13,600 \\
\hline US from Slater Run & $40^{\circ} 35^{\prime} 45^{\prime \prime}$ & $82^{\circ} 24^{\prime} 54^{\prime \prime}$ & 143 & 7.42 & 2.18 & 6,540 & 8,080 & 9,220 & 10,400 & 13,000 & 14,400 \\
\hline DS from Slater Run & $40^{\circ} 35^{\prime} 46^{\prime \prime}$ & $82^{\circ} 24^{\prime} 53^{\prime \prime}$ & 152 & 7.43 & 2.08 & 6,910 & 8,530 & 9,750 & 11,000 & 13,800 & 15,200 \\
\hline \multicolumn{12}{|c|}{ Cedar Fork } \\
\hline Above unnamed tributary 2 & $40^{\circ} 37^{\prime} 17^{\prime \prime}$ & $82^{\circ} 37^{\prime} 00^{\prime \prime}$ & 16.7 & 31.3 & 0.32 & 2,100 & 2,730 & 3,210 & 3,700 & 4,860 & 5,110 \\
\hline Above unnamed tributary 1 & $40^{\circ} 37^{\prime} 18^{\prime \prime}$ & $82^{\circ} 35^{\prime} 53^{\prime \prime}$ & 25.1 & 27.4 & 0.29 & 2,810 & 3,640 & 4,270 & 4,920 & 6,440 & 6,790 \\
\hline Above Steel Run & $40^{\circ} 37^{\prime} 00^{\prime \prime}$ & $82^{\circ} 33^{\prime} 59^{\prime \prime}$ & 38.1 & 23.5 & 0.34 & 3,710 & 4,790 & 5,600 & 6,440 & 8,400 & 8,890 \\
\hline At mouth & $40^{\circ} 37^{\prime} 28^{\prime \prime}$ & $82^{\circ} 32^{\prime} 11^{\prime \prime}$ & 47.7 & 18.7 & 0.47 & 4,110 & 5,270 & 6,140 & 7,050 & 9,130 & 9,730 \\
\hline
\end{tabular}

${ }^{1}$ The 1-percent plus flood elevation is defined by the Federal Emergency Management Agency as a flood elevation derived by using streamflows that include the average predictive error for the regression equation streamflow calculation for the Flood Risk project. This error is then added to the 1-percent annual exceedance probability flood streamflow to calculate the new 1-percent plus streamflow. In the case of this study, the average predictive error for the 1-percent annual exceedance probability flood is 38 percent. Therefore, the 1-percent plus annual exceedance probability flood streamflows were calculated to be 138 percent of the 1-percent annual exceedance probability flood streamflows.

${ }^{2}$ The main channel slope is determined by the new channel slope characteristic (SL10-85) (Koltun and others, 2006).

${ }^{3}$ Determined using StreamStats web application for Ohio that solves regional regression equations (Koltun and others, 2006). 
Table 3. Peak-flood estimates for the 10-, 4-, 2-, 1-, and 0.2-percent annual exceedance probability floods are reported in Koltun and others (2006), and weighting ratio equal to the weighted regression estimate divided by the regression estimate.

[USGS, U.S. Geological Survey; $\mathrm{ft}^{3} / \mathrm{s}$, cubic foot per second; \%, percent]

\begin{tabular}{|c|c|c|c|c|c|c|}
\hline \multirow{2}{*}{$\begin{array}{l}\text { Site name and } \\
\text { USGS station number }\end{array}$} & \multicolumn{5}{|c|}{ Annual exceedance probability flood-peak streamflows ( $\left.\mathrm{ft}^{3} / \mathrm{s}\right)$} & \multirow{2}{*}{ Estimate type } \\
\hline & $10 \%$ & $4 \%$ & $2 \%$ & $1 \%$ & $0.2 \%$ & \\
\hline \multirow{3}{*}{$\begin{array}{l}\text { Clear Fork at Butler, } \\
\text { Ohio }(03132000)\end{array}$} & 7,250 & 10,100 & 12,700 & 15,800 & 25,100 & Log Pearson Type III. \\
\hline & 7,160 & 9,830 & 12,200 & 14,800 & 22,600 & Weighted. \\
\hline & 1.147 & 1.273 & 1.383 & 1.493 & 1.808 & Weighting ratio. \\
\hline
\end{tabular}

Table 4. Summary of the final 10-, 4-, 2-, 1-, and 0.2-percent and 1-percent plus annual exceedance probability flood-peak streamflow estimates and locations for the selected streams in Richland County, Ohio.

$\left[\mathrm{ft}^{3} / \mathrm{s}\right.$, cubic foot per second; \%, percent]

\begin{tabular}{|c|c|c|c|c|c|c|}
\hline \multirow{2}{*}{ Location description } & \multicolumn{6}{|c|}{ Annual exceedance probability flood-peak streamflows ${ }^{1}\left(\mathrm{ft}^{3} / \mathrm{s}\right)$} \\
\hline & $10 \%$ & $4 \%$ & $2 \%$ & $1 \%$ & $0.2 \%$ & $1 \%$ plus \\
\hline \multicolumn{7}{|c|}{ Clear Fork Mohican River } \\
\hline At Lexington Springmill Road & 2,910 & 4,000 & 4,950 & 6,020 & 9,110 & 8,300 \\
\hline At U.S. Route 42 & 3,240 & 4,440 & 5,510 & 6,690 & 10,100 & 9,230 \\
\hline Upstream from Cedar Fork & 3,630 & 4,940 & 6,100 & 7,390 & 11,100 & 10,200 \\
\hline 1,300 feet downstream from Hines Avenue & 6,200 & 8,480 & 10,500 & 12,800 & 19,300 & 17,600 \\
\hline Upstream from Honey Creek & 6,280 & 8,570 & 10,600 & 12,900 & 19,500 & 17,800 \\
\hline Upstream from Smoky Run & 7,150 & 9,780 & 12,100 & 14,800 & 22,400 & 20,300 \\
\hline Upstream from Slater Run & 7,500 & 10,300 & 12,800 & 15,500 & 23,500 & 21,500 \\
\hline Above unnamed tributary 1 & 2,810 & 3,640 & 4,270 & 4,920 & 6,440 & 6,790 \\
\hline Above Steel Run & 3,710 & 4,790 & 5,600 & 6,440 & 8,400 & 8,890 \\
\hline At mouth & 4,110 & 5,270 & 6,140 & 7,050 & 9,130 & 9,730 \\
\hline
\end{tabular}

${ }^{1}$ Determined using StreamStats web application for Ohio, which solves regional regression equations (Koltun and others, 2006).

Table 5. Selected hydraulic parameters used in the hydraulic models.

$[\mathrm{ft} / \mathrm{ft}$, feet per foot]

\begin{tabular}{|c|c|c|c|c|c|c|c|c|c|c|}
\hline \multirow[b]{2}{*}{ Stream name } & \multirow[b]{2}{*}{$\begin{array}{l}\text { Baseline } \\
\text { reference } \\
\text { location' }\end{array}$} & \multirow[b]{2}{*}{$\begin{array}{l}\text { Study } \\
\text { reach } \\
\text { length } \\
\text { (mile) }\end{array}$} & \multirow[b]{2}{*}{$\begin{array}{l}\text { Number of } \\
\text { surveyed } \\
\text { cross } \\
\text { sections }\end{array}$} & \multirow[b]{2}{*}{$\begin{array}{l}\text { Number of cross } \\
\text { sections derived } \\
\text { from digital } \\
\text { elevation model }\end{array}$} & \multirow[b]{2}{*}{$\begin{array}{l}\text { Number of } \\
\text { hydraulic } \\
\text { structures }\end{array}$} & \multirow[b]{2}{*}{$\begin{array}{c}\text { Slope used for } \\
\text { normal depth } \\
\text { calculation } \\
\text { (ft/ft) }\end{array}$} & \multicolumn{4}{|c|}{ Manning's roughness coefficient $(n)$} \\
\hline & & & & & & & $\begin{array}{l}\text { Lowest } \\
\text { value } \\
\text { for main } \\
\text { channel }\end{array}$ & $\begin{array}{l}\text { Highest } \\
\text { value } \\
\text { for main } \\
\text { channel }\end{array}$ & $\begin{array}{c}\text { Lowest } \\
\text { value for } \\
\text { overbanks }\end{array}$ & $\begin{array}{c}\text { Highest } \\
\text { value for } \\
\text { overbanks }\end{array}$ \\
\hline $\begin{array}{l}\text { Clear Fork } \\
\text { Mohican River }\end{array}$ & $\begin{array}{l}\text { Pleasant } \\
\text { Hill Road }\end{array}$ & 18.6 & 132 & 393 & 33 & 0.00260 & 0.036 & 0.044 & 0.030 & 0.100 \\
\hline
\end{tabular}

${ }^{1}$ Location from which the river stationing is measured upstream, in feet.

${ }^{2}$ Normal depth is the depth of uniform flow. Flow is considered uniform if the energy line, water surface, and channel bottom all are parallel (Chow, 1959). 
The USGS field crews surveyed 161 (132 for Clear Fork Mohican River and 29 for Cedar Fork) channel cross sections (table 5) and 41 hydraulic structures. The cross sections were surveyed to provide ground elevations below stream-water surfaces that cannot be provided by lidar. The structures were surveyed for geometrical data that have the potential to affect water-surface elevations during floods along the streams.

\section{Topographic and Bathymetric Data}

Cross-section elevation data were obtained from a digital elevation model (DEM) that was provided to the USGS by Richland County, Ohio (Richland County Regional Planning Commission, 2018). The DEM was derived from light detection and ranging (lidar) data collected during April 2005. The lidar data have horizontal resolution that meets National Map Accuracy Standards and vertical accuracy of plus or minus $1.0 \mathrm{ft}$ at a 95 -percent confidence level for the "open terrain" land-cover category (root-mean-square error of $0.5 \mathrm{ft}$ ) (Federal Geographic Data Committee, 1998). By these criteria, the lidar data support production of 2-foot contours (Dewberry, 2012); the final DEM has a vertical accuracy of $1.0 \mathrm{ft}$. The DEM data were converted into 2-foot contours by Aerocon Photogrammetric Service, Inc. under contract with Richland County, Ohio. By using HEC-GeoRAS, elevation data were extracted from the DEM for 531 cross sections (table 5) for use in the Clear Fork Mohican River (393 cross sections) and Cedar Fork (138 cross sections) HEC-RAS models. The maximum distances between cross sections for Clear Fork Mohican River and Cedar Fork were 482 and $309 \mathrm{ft}$, respectively.

DEM-derived cross sections were colocated with the locations of the in-channel field-surveyed cross sections where available. In those cases, in-channel data were directly merged with the DEM data. The bathymetry for the DEM-derived cross sections that did not have surveyed in-channel cross sections were estimated by interpolating between the closest field-surveyed cross sections.

\section{Hydraulic Modeling}

The hydraulic baseline for Clear Fork Mohican River is referenced to feet upstream from Pleasant Hill Road (to match previous FIS work). The FIS reach limits were from a point approximately $700 \mathrm{ft}$ downstream from Benedict Road in Butler, Ohio (river station 16,605 ft) to approximately $100 \mathrm{ft}$ upstream from Gass Road near Lexington, Ohio (river station 114,793 ft); a total reach length of 18.6 miles. For Cedar Fork, the hydraulic baseline is referenced to feet upstream from the mouth and the FIS reach limits are from the mouth (river station 63) upstream to the Richland County line (Wirick Road); a total reach length of 5.9 miles.

The downstream boundary condition for Clear Fork Mohican River and Cedar Fork were set to be normal depth and were calculated from field surveys near their corresponding downstream limits using water-surface slopes of 0.0026 and 0.00126 foot per foot, respectively. Normal depth is defined as the depth of uniform flow. Flow is considered uniform if the energy line, water surface, and channel bottom all are parallel (Chow, 1959).

For Clear Fork Mohican River, the HEC-RAS model was calibrated to 16 flood events at the Bellville streamgage (USGS station number 03131982) using stage-streamflow rating number 3.0 and at a submersible pressure transducer near the downstream corporate limits for Bellville. Model calibration was accomplished by adjusting Manning's $n$ values until the results of the hydraulic computations closely agreed with the target water-surface elevations for modeled streamflows. Absolute differences between rating number 3.0 and simulated water-surface elevations for stages 9 to $11 \mathrm{ft}$ at the USGS streamgage were equal to or less than $0.05 \mathrm{ft}$. The differences between recorded and simulated water-surface elevations for the $16 \mathrm{flood}$ events ranged from -0.05 to $0.03 \mathrm{ft}$ at the streamgage (a root-mean-square error of $0.03 \mathrm{ft}$ ) and from -0.15 to $0.15 \mathrm{ft}$ for the non-clogged flood events at the submersible pressure transducer (table 6). For Cedar Fork, no streamgage data were available for calibration.

Approximately 1.2 miles downstream from Lexington (fig. 1) the flood flows for Clear Fork Mohican River split and rejoin after traveling approximately 0.75 mile. For each modeled profile, a series of streamflow combinations that summed to the total streamflows were routed down the main channel and overflow channel reaches until the watersurface elevations were balanced at the beginning and end of the split flow area. A summary of the overflow analysis is given in table 7 .

\section{Development of Flood Profiles}

The calibrated HEC-RAS model was used to generate seven flood profiles corresponding to the 10-, 4-, 2-, 1-, and 0.2-percent and 1-percent plus AEP floods, and a regulatory floodway. The profiles are presented in tabular format in an accompanying data release (Ostheimer, 2019) and in graphical format (appendix 1) at the end of this report. These profiles show computed water-surface elevations as a function of 
Table 6. Calibration results of the Clear Fork Mohican River hydraulic model to recorded water-surface elevations for 16 flood events.

$\left[\mathrm{ft}^{3} / \mathrm{s}\right.$, cubic foot per second; ft, foot; NAVD 88, North American Vertical Datum of 1988; n/a, not applicable]

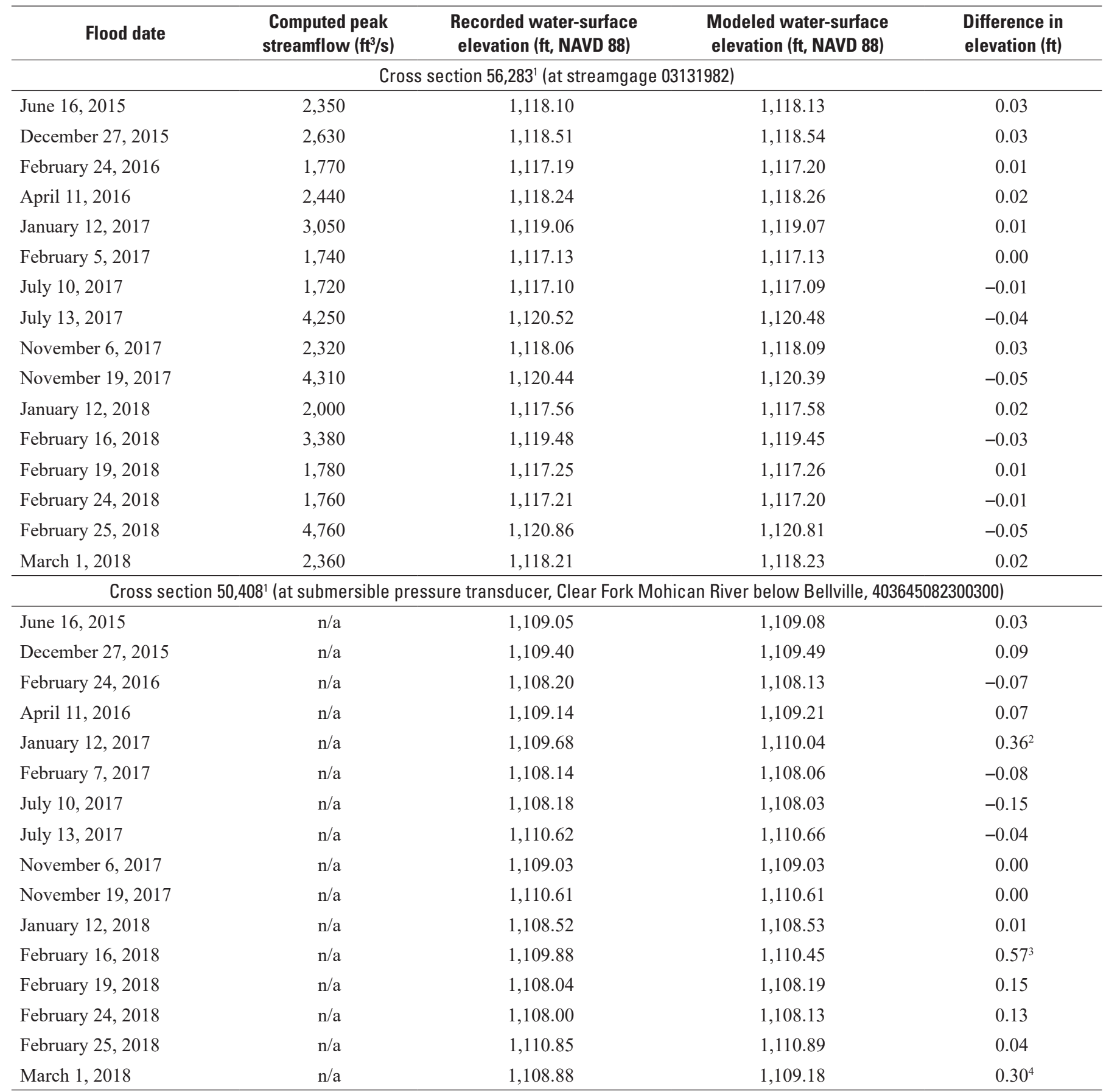

${ }^{1}$ Cross-section identification numbers are referenced (in feet) to the longitudinal baseline used in the hydraulic model.

${ }^{2}$ Sometime before or during the January 2017 flood event, the submersible pressure transducer became clogged with silt and debris, likely causing an incorrect low reading.

${ }^{3}$ The submersible pressure transducer possibly was clogged before or during the February 16, 2018, flood event, causing an incorrect low reading. The clog seems to have been temporary because the preceding and following events indicate good agreement.

${ }^{4}$ The submersible pressure transducer was noted as partially clogged during the data download on March 22, 2018. The pressure transducer likely became clogged after the February 25, 2018, flood event, causing an incorrect low reading. 
Table 7. Results of the Clear Fork Mohican River overflow analysis.

$\left[\mathrm{ft}^{3} / \mathrm{s}\right.$, cubic foot per second; \%, percent]

\begin{tabular}{|c|c|c|c|c|c|c|c|}
\hline \multirow{2}{*}{ Location } & \multicolumn{6}{|c|}{ Annual exceedance probability flood-peak streamflows ( $\left.\mathrm{ft}^{3} / \mathrm{s}\right)$} & \multirow{2}{*}{$\begin{array}{l}\text { Regulatory } \\
\text { floodway }\end{array}$} \\
\hline & $10 \%$ & $4 \%$ & $2 \%$ & $1 \%$ & $0.2 \%$ & 1-percent plus ${ }^{1}$ & \\
\hline Main channel & 2,980 & 3,780 & 4,410 & 5,080 & 6,780 & 6,400 & 5,080 \\
\hline Total above and below split flow & 3,600 & 4,920 & 6,070 & 7,360 & 11,100 & 10,200 & 7,360 \\
\hline $\begin{array}{l}\text { Percent of total streamflow in } \\
\text { overflow channel }\end{array}$ & $17 \%$ & $23 \%$ & $27 \%$ & $31 \%$ & $39 \%$ & $37 \%$ & $31 \%$ \\
\hline
\end{tabular}

${ }^{1}$ The 1-percent plus flood elevation is defined by the Federal Emergency Management Agency as a flood elevation derived by using streamflows that include the average predictive error for the regression equation streamflow calculation for the Flood Risk project. This error is then added to the 1-percent annual exceedance probability flood streamflow to calculate the new 1-percent plus streamflow. In the case of this study, the average predictive error for the 1-percent annual exceedance probability flood is 38 percent. Therefore, the 1-percent plus annual exceedance probability flood streamflows were calculated to be 138 percent of the 1-percent annual exceedance probability flood streamflows.

${ }^{2} \mathrm{~A}$ "regulatory floodway" means the channel of a river or other watercourse and the adjacent land areas that must be reserved to discharge the base flood without cumulatively increasing the water-surface elevation more than a designated height (Federal Emergency Management Agency, 2018).

distance from a reference location. Also depicted on the profile plots are the minimum channel elevations at each cross section and the hydraulic structures. All elevations presented in the profile plots are referenced to the North American Vertical Datum of 1988.

\section{Development of Flood-Inundation Maps}

Flood-inundation maps were created in a GIS for three flood profiles (1- and 0.2-percent AEP floods and a regulatory floodway) required by FEMA for a FIS by combining flood-profile data with digital elevation data. The DEM was derived from the lidar data described previously in the section "Topographic and Bathymetric Data" and has an estimated vertical accuracy of $1 \mathrm{ft}$. Initial flood-inundation boundaries were developed for each simulated profile by use of HECGeoRAS software (U.S. Army Corps of Engineers, 2009). Flood-inundation boundaries and depth grids for the inundated areas were modified in ArcMap (Environmental Systems Research Institute, 2017), as required, to ensure hydraulically reasonable transitions of the flood boundaries between modeled cross sections.

Any inundated areas that were disconnected from the main channel were examined to identify artificial connections with the main river, such as through culverts under roadways. Where such connections existed, the mapped inundated areas were retained in their respective flood maps; otherwise, the disconnected inundated areas were deleted. The flood-inundation areas were overlain on high-resolution, georeferenced aerial photographs of the study area. These flood-inundation maps are presented in appendix 2 .

\section{Disclaimer for Flood-Inundation Maps}

The flood-inundation maps should not be used for navigation, regulatory, permitting, or other legal purposes. The USGS provides these maps "as-is" for a quick reference, emergency planning tool but assumes no legal liability or responsibility resulting from the use of this information.

\section{Uncertainties and Limitations Regarding Use of Flood-Inundation}

Although the flood-inundation maps represent the boundaries of inundated areas with a distinct line, some uncertainty is associated with these maps. The flood boundaries shown were estimated on the basis of water stages and streamflows at selected USGS streamgages. Water-surface elevations along the stream reaches were estimated by steady-state hydraulic modeling, assuming unobstructed flow, and using streamflows and hydrologic conditions anticipated at the USGS streamgage. The hydraulic model reflects the land-cover characteristics and any bridge, dam, levee, or other hydraulic structures existing as of January 2018. Unique meteorological factors (timing and distribution of precipitation) may cause actual streamflows along the modeled reach to vary from those assumed during a flood, which may lead to deviations in the water-surface elevations and inundation boundaries shown. Additional areas may be flooded due to unanticipated conditions such as changes in the streambed elevation or roughness, backwater into major tributaries along a main stem river, or backwater from localized debris or ice jams. The accuracy of the floodwater extent portrayed on these maps will vary with the accuracy of the DEM used to simulate the land surface. 
If this series of flood-inundation maps will be used in conjunction with NWS river forecasts, the user should be aware of additional uncertainties that may be inherent or factored into NWS forecast procedures. The NWS uses forecast models to estimate the quantity and timing of water flowing through selected stream reaches in the United States. These forecast models (1) estimate the amount of runoff generated by precipitation and snowmelt, (2) simulate the movement of floodwater as it proceeds downstream, and (3) predict the flow and stage (and water-surface elevation) for the stream at a given location (AHPS forecast point) throughout the forecast period (every 6 hours and 3 to 5 days out in many locations). For more information on AHPS forecasts, refer to http://water. weather.gov/ahps/pcpn_and_river_forecasting.pdf. Additional uncertainties and limitations pertinent to this study are described elsewhere in this report.

\section{Summary}

The U.S. Geological Survey, in cooperation with the Muskingum Watershed Conservancy District updated and expanded the Flood Insurance Study for Richland County, Ohio. Flood profiles were developed for the 10-, 4-, 2-, 1-, and 0.2 -percent and 1-percent plus annual exceedance probability floods and for a regulatory floodway for both Clear Fork Mohican River and Cedar Fork. Mapping for each stream was developed for the 1- and 0.2-percent annual exceedance probability floods and a regulatory floodway. The 1-percent plus flood elevation is defined by the Federal Emergency Management Agency as a flood elevation derived by using streamflows that include the average predictive error for the regression equation streamflow calculation for the Flood Risk project. This error is then added to the 1-percent annual exceedance probability flood streamflow to calculate the new 1-percent plus streamflow. The study comprised an 18.6-mile reach of the Clear Fork Mohican River and a 5.9-mile reach of Cedar Fork.

The U.S. Army Corps of Engineers' Hydrologic Engineering Center-River Analysis System program was used to compute water-surface profiles and delineate estimated flood-inundation area boundaries. Model input included digital elevation model derived cross sections supplemented with field surveys of open channel cross sections and hydraulic structures, field estimates of roughness values, and annual exceedance probability flood estimates from regional regression equations and historical streamflow data. The hydraulic model for Clear Fork Mohican River was calibrated to 16 flood events. The flood-inundation areas were overlain on high-resolution, georeferenced aerial photographs of the study area. The flood profiles can help emergency planners and the public make more informed decisions about flood risk.

\section{References Cited}

Chow, V.T., 1959, Open channel hydraulics: New York, McGraw Hill, 680 p.

Cross, W.P., and Brooks, H.P., 1959, Floods of JanuaryFebruary 1959 in Ohio, U.S. Geological Survey Circular $418,54 \mathrm{p}$.

Dewberry, 2012, National Enhanced Elevation Assessment final report: Fairfax, Va., 84 p., accessed September 19, 2013, at http://www.dewberry.com/services/geospatial/ national-enhanced-elevation-assessment.

Environmental Systems Research Institute, 2017, About ArcGIS-The mapping and analytics platform: accessed April 18, 2017, at http://www.esri.com/software/arcgis/.

Federal Emergency Management Agency, 2011, Flood Insurance Study, Richland County, Ohio, and incorporated areas: Washington D.C., Flood Insurance Study Number 39139CV000A, 102 p., accessed March 7, 2019, at https:// map1.msc.fema.gov/data/39/S/PDF/39139CV000A.pdf?LO $\mathrm{C}=4 \mathrm{f} 29 \mathrm{c} 1 \mathrm{~d} 0437 \mathrm{cc} 43574 \mathrm{~cd} 55 \mathrm{c} 2691 \mathrm{eb} 356$.

Federal Emergency Management Agency, 2018, Floodway: accessed April 30, 2018, at https://www.fema.gov/floodway.

Federal Geodetic Control Committee, 1984, Standards and specifications for geodetic control networks: Rockville, Md., Federal Geodetic Control Committee, accessed September 19, 2018, at https://www.ngs.noaa.gov/FGCS/ tech_pub/1984-stds-specs-geodetic-control-networks.pdf.

Federal Geographic Data Committee, 1998, Geospatial positioning standards, Part 3-National standard for spatial data accuracy: Reston, Va., U.S. Geological Survey, FGDCSTD-007.3-1998, accessed August 28, 2018, at https:// www.fgdc.gov/standards/projects/FGDC-standards-projects/ accuracy/part3/chapter3/.

Interagency Committee on Water Data, 1982, Guidelines for determining flood flow frequency: Reston, Va., U.S. Geological Survey, Bulletin 17B of the Hydrology Subcommittee, Office of Water Data Coordination, $183 \mathrm{p}$.

Koltun, G.F., Kula, S.P., and Puskas, B.M., 2006, A streamflow statistics (StreamStats) web application for Ohio: U.S. Geological Survey Scientific Investigations Report 2006-5312, 62 p., accessed June 30, 2017, at http://pubs.usgs.gov/sir/2006/5312/.

Mayo, R.I., and Mangus, J.P., 1989, Flood of July 1-2, 1987, in north-central Ohio, U.S. Geological Survey Open File Report 89-376, 16 p. 
National Weather Service, 2018, Advanced Hydrologic Prediction Service, Clear Fork Mohican River at Bellville: accessed April 30, 2018, at http://water.weather.gov/ahps2/ hydrograph.php?wfo=cle\&gage=bleo 1 .

Ohio Geographically Referenced Information Program, 2007, Ohio Statewide Imagery Program downloads: accessed March 2, 2015, at http://ogrip.oit.ohio.gov/ProjectsInitiatives/OSIPDataDownloads.aspx.

Ostheimer, C.J., 2019, Geospatial datasets and hydraulic models for the Clear Fork Mohican River and Cedar Fork in Richland County, Ohio: U.S. Geological Survey data release, https://doi.org/10.5066/P9NMXM5B.

Richland County Regional Planning Commission, 2018, RCRPC - Who we are: Richland County Regional Planning Commission web page, accessed June 30, 2017, at http://www.rcrpc.org.

Rydlund, P.H., Jr.; and Densmore, B.K., 2012, Methods of practice and guidelines for using survey-grade global navigation satellite systems (GNSS) to establish vertical datum in the United States Geological Survey: U.S. Geological Survey Techniques and Methods, book 11, chap. D1, 102 p. with appendixes.

U.S. Army Corps of Engineers, 2009, HEC-GeoRAS, GIS tools for support of HEC-RAS using ArcGIS-User's manual, version 4.2: Davis, Calif., U.S. Army Corps of Engineers Institute for Water Resources, Hydrologic Engineering Center [variously paged], accessed August 28,2018, at http://www.hec.usace.army.mil/software/hec-georas/ documentation/HEC-GeoRAS42_UsersManual.pdf.

U.S. Army Corps of Engineers, 2010, HEC-RAS River Analysis System-Hydraulic reference manual, version 4.1: Davis, Calif., U.S. Army Corps of Engineers Institute for Water Resources, Hydrologic Engineering Center, [variously paged], accessed August 28, 2018, at https:// www.hec.usace.army.mil/software/hec-ras/documentation/ hec-ras_4.1_reference_manual.pdf.
U.S. Census Bureau, 2010, Profile of general population and housing characteristics-2010; 2010 demographic profile data: accessed March 7, 2019, at https:// factfinder.census.gov/bkmk/table/1.0/en/DEC/10_DP/ DPDP1/0500000US39139.

U.S. Geological Survey, 2017a, USGS 03131898 Clear Fork Reservoir near Lexington, Ohio: U.S. Geological Survey National Water Information System, accessed June 30, 2017, at http://waterdata.usgs.gov/oh/nwis/ inventory/?site_no $=03131898$.

U.S. Geological Survey, 2017b, USGS 03131982 Clear Fork Mohican River at Bellville, Ohio: U.S. Geological Survey National Water Information System, accessed June 30, 2017, at http://waterdata.usgs.gov/oh/nwis/ inventory/?site_no $=03131982$.

U.S. Geological Survey, 2017c, USGS 03131965 Cedar Fork above Bellville, Ohio: U.S. Geological Survey National Water Information System, accessed August 7, 2017, at http://waterdata.usgs.gov/oh/nwis/inventory/?site no $=03131965$.

U.S. Geological Survey, 2017d, USGS surface-water data for the Nation: U.S. Geological Survey National Water Information System, accessed June 29, 2017, at http://waterdata.usgs.gov/nwis/sw. 


\section{Appendix 1}

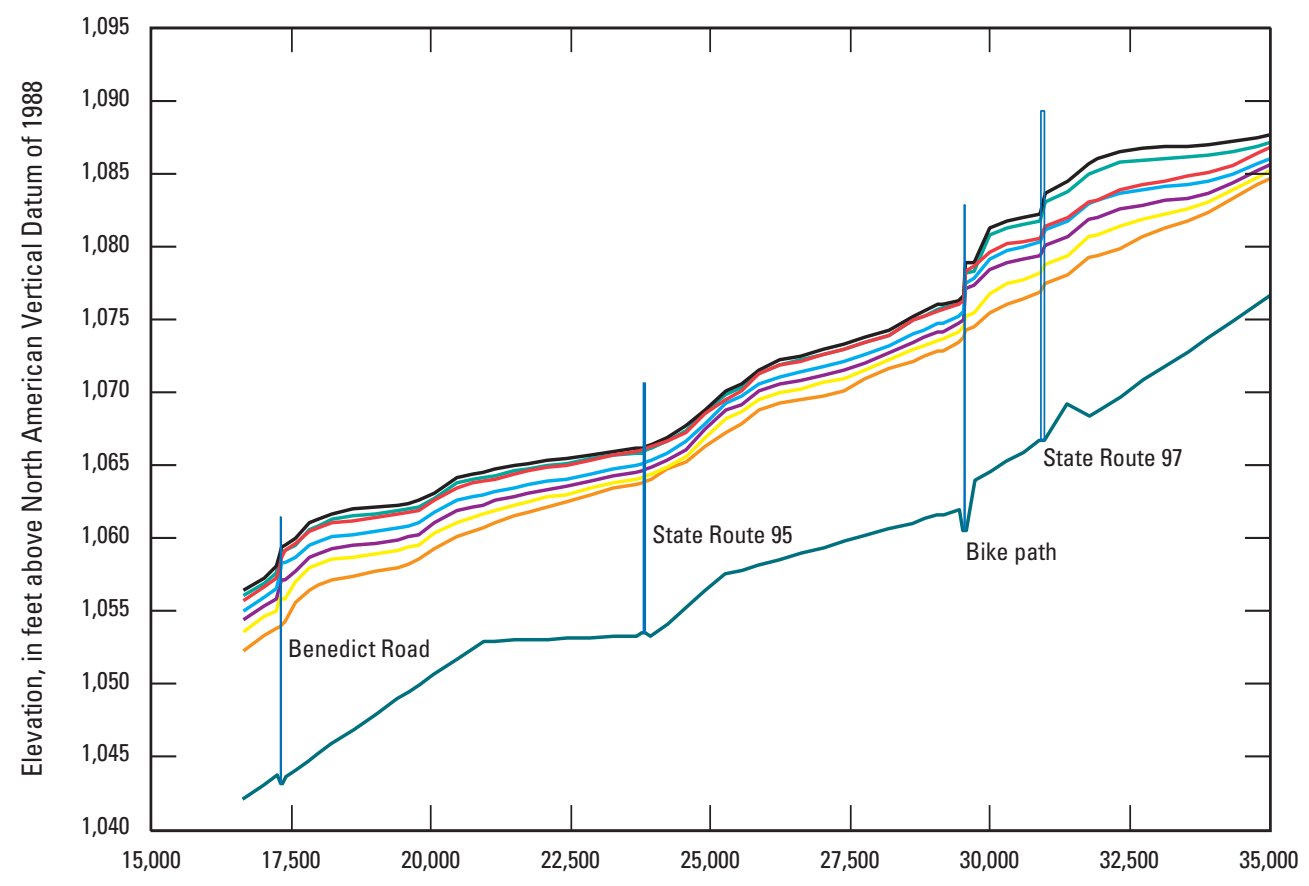

EXPLANATION

Hydraulic structures

0.2-percent annual exceedance probability

1-percent plus annual exceedance probability

Regulatory floodway

1-percent annual exceedance probability

2-percent annual exceedance probability

4-percent annual exceedance probability

10-percent annual exceedance probability

Minimum channel elevation

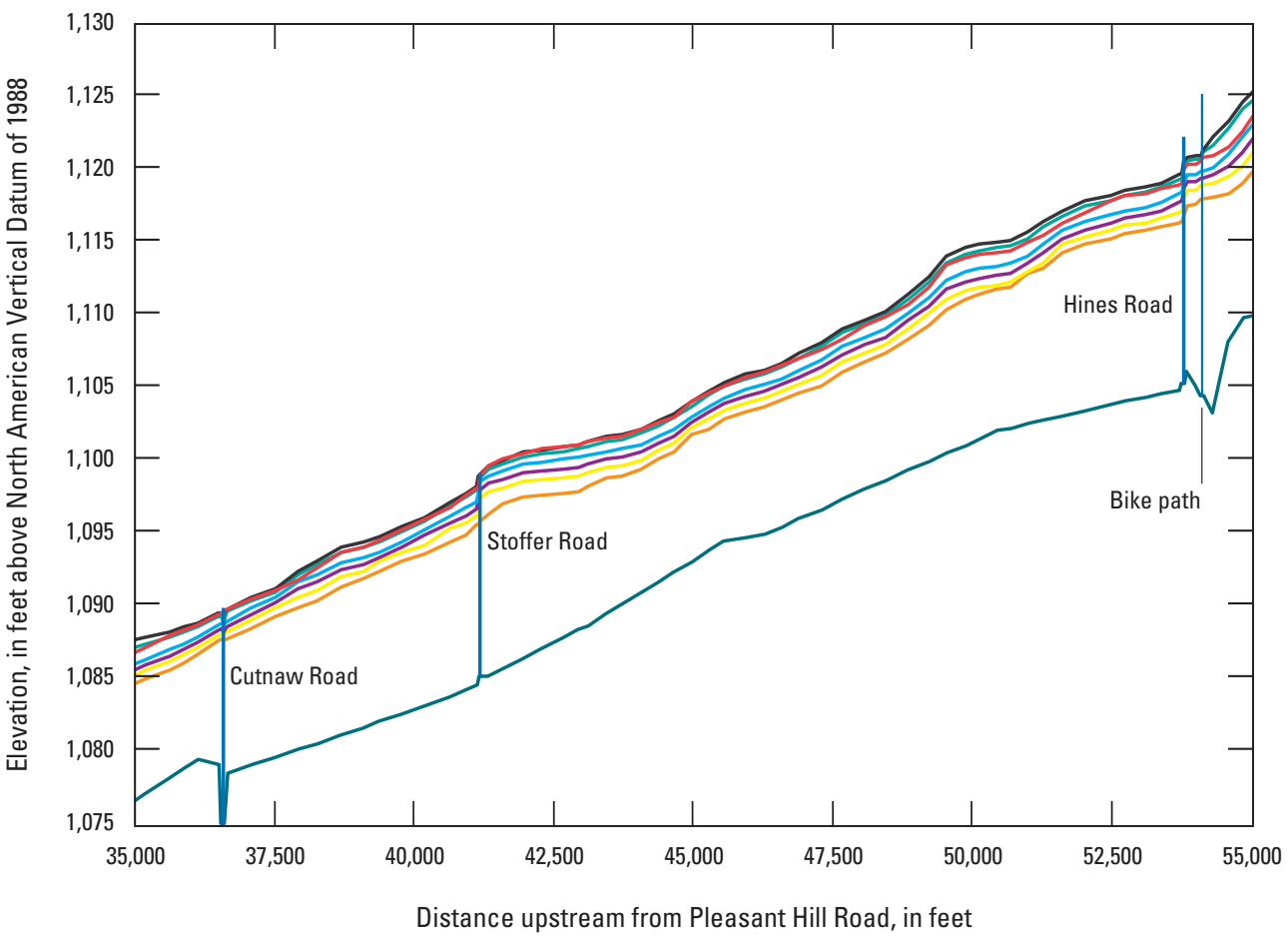

Note: The 1-percent plus flood elevation is defined by Federal Emergency Management Agency (FEMA) as a flood elevation derived by using streamflows that include the average predictive error for the regression equation streamflow calculation for the Flood Risk project. This error is then added to the 1-percent annual exceedance probability flood streamflow to calculate the new 1-percent plus streamflow. In the case of this study, the average predictive error for the 1-percent annual exceedance probability flood is 38 percent. Therefore, the 1-percent plus annual exceedance probability flood streamflows were calculated to be 138 percent of the 1-percent annual exceedance probability flood streamflows.

Figure 1.1. Computed water-surface profiles for flood events with annual exceedance probabilities of 10-, 4-, 2-, 1-, and 0.2-percent and 1-percent plus for the Clear Fork Mohican River, Richland County, Ohio. 


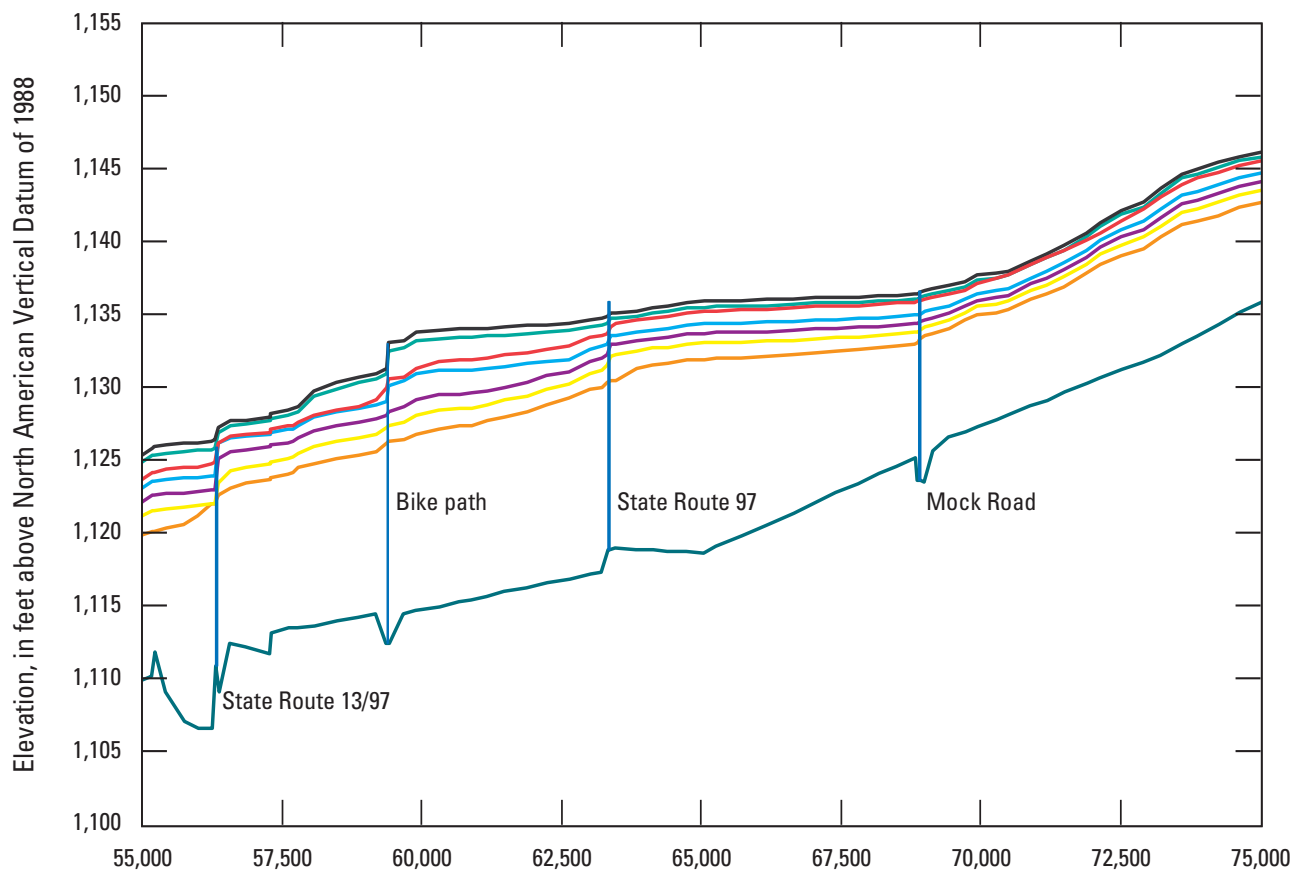

\section{EXPLANATION}

Hydraulic structures

0.2-percent annual exceedance probability

1-percent plus annua exceedance probability

Regulatory floodway

1-percent annual exceedance probability

2-percent annual exceedance probability

4-percent annual exceedance probability

10-percent annual exceedance probability

\section{Minimum channel elevation}

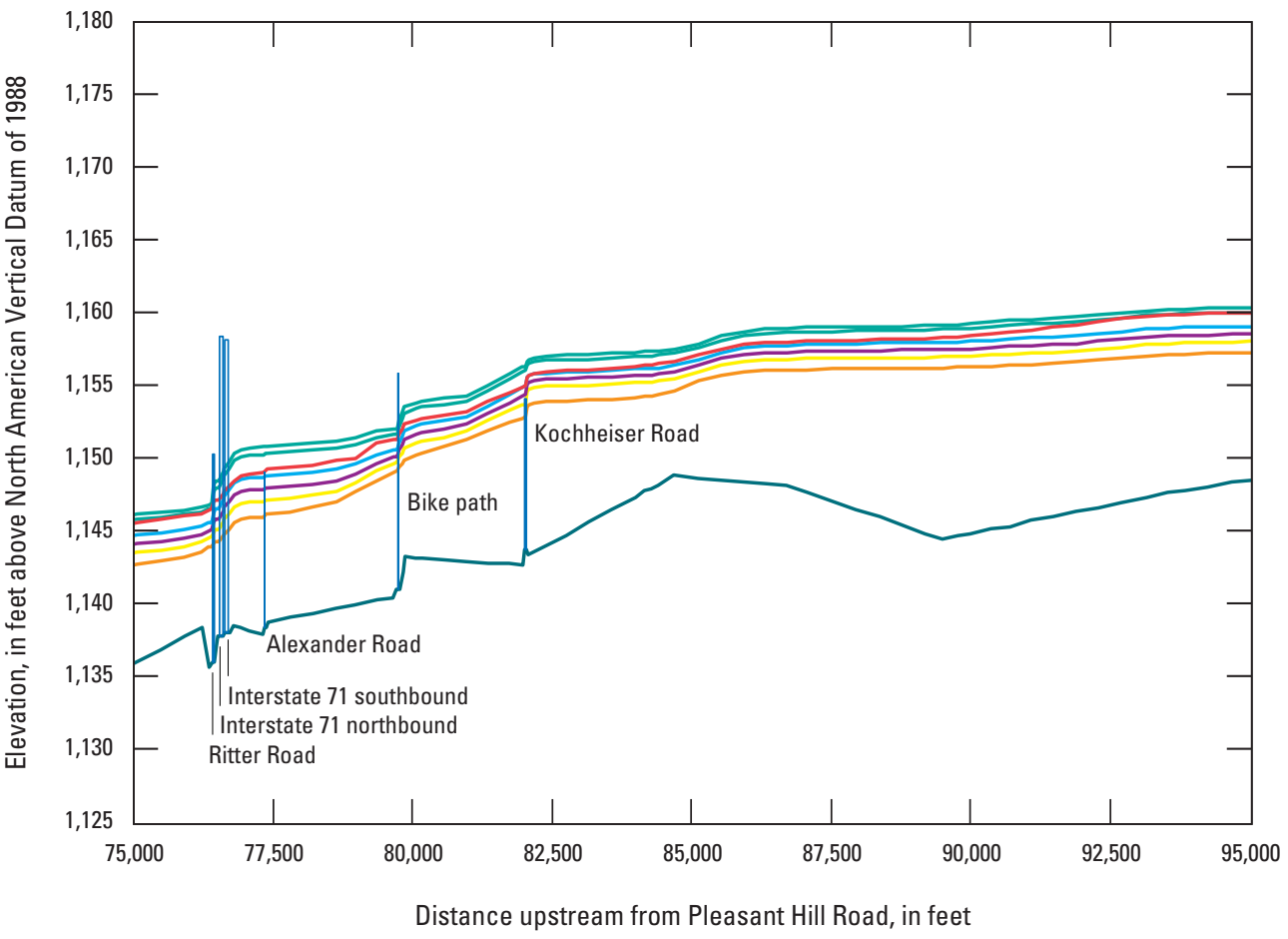

Note: The 1-percent plus flood elevation is defined by Federal Emergency Management Agency (FEMA) as a flood elevation derived by using streamflows that include the average predictive error for the regression equation streamflow calculation for the Flood Risk project. This error is then added to the 1-percent annual exceedance probability flood streamflow to calculate the new 1-percent plus streamflow. In the case of this study, the average predictive error for the 1-percent annual exceedance probability flood is 38 percent. Therefore, the 1-percent plus annual exceedance probability flood streamflows were calculated to be 138 percent of the 1-percent annual exceedance probability flood streamflows.

Figure 1.1. Computed water-surface profiles for flood events with annual exceedance probabilities of 10-, 4-, 2-, 1-, and 0.2-percent and 1-percent plus for the Clear Fork Mohican River, Richland County, Ohio.-Continued 


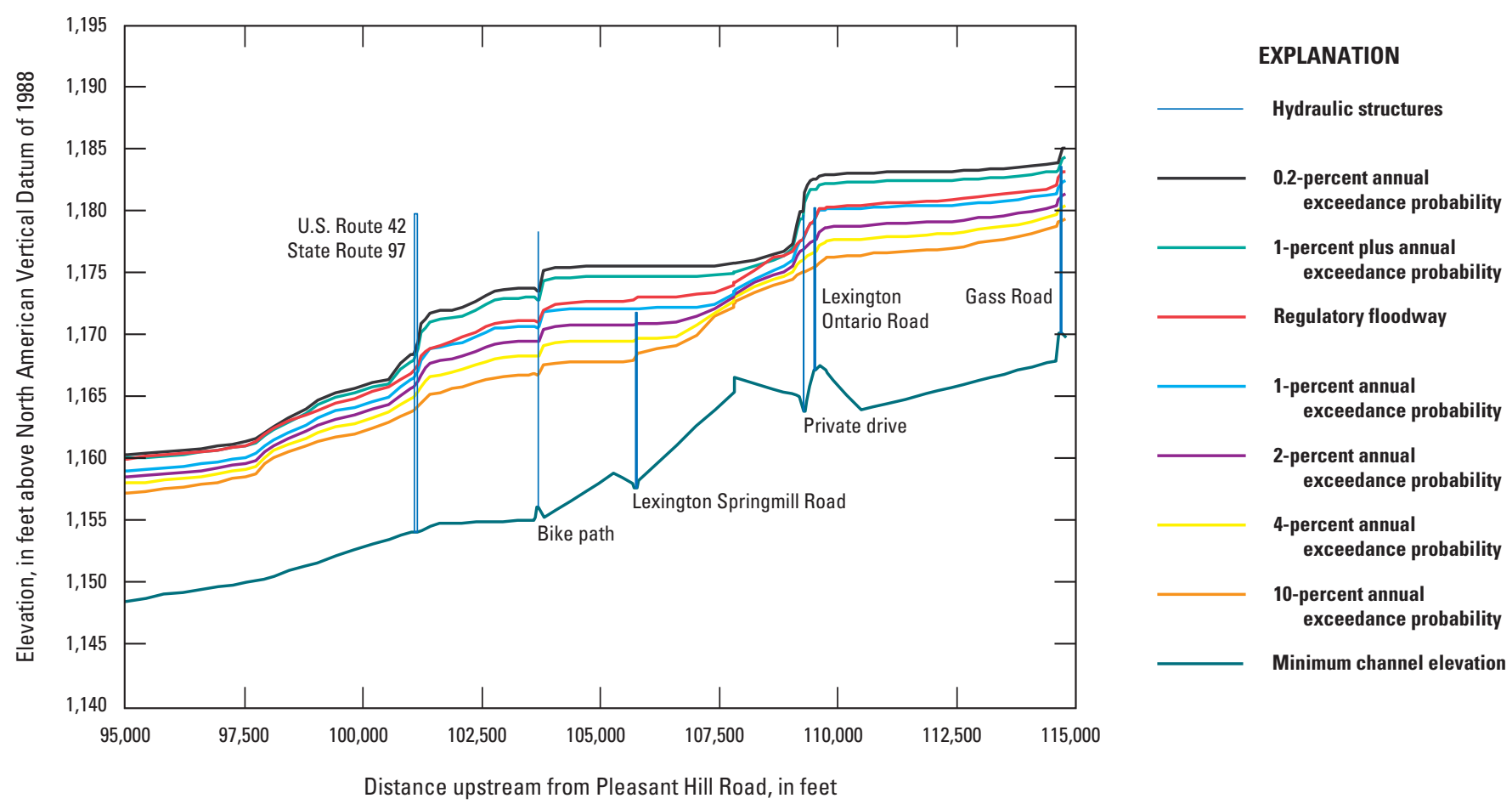

Note: The 1-percent plus flood elevation is defined by Federal Emergency Management Agency (FEMA) as a flood elevation derived by using streamflows that include the average predictive error for the regression equation streamflow calculation for the Flood Risk project. This error is then added to the 1-percent annual exceedance probability flood streamflow to calculate the new 1-percent plus streamflow. In the case of this study, the average predictive error for the 1-percent annual exceedance probability flood is 38 percent. Therefore, the 1-percent plus annual exceedance probability flood streamflows were calculated to be 138 percent of the 1-percent annual exceedance probability flood streamflows.

Figure 1.1. Computed water-surface profiles for flood events with annual exceedance probabilities of 10-, 4-, 2-, 1-, and 0.2-percent and 1-percent plus for the Clear Fork Mohican River, Richland County, Ohio.-Continued 


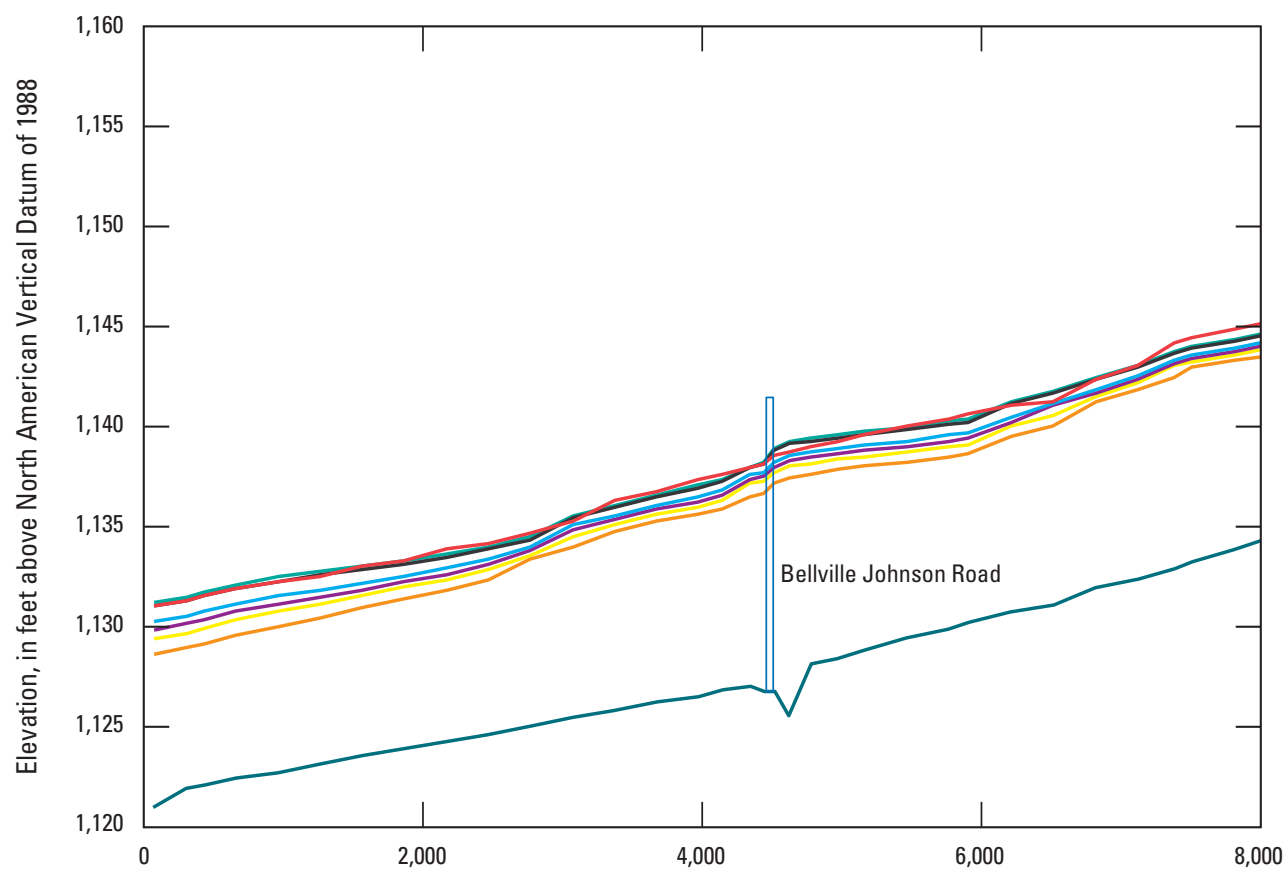

EXPLANATION

Hydraulic structures

0.2-percent annual exceedance probability

1-percent plus annual exceedance probability

Regulatory floodway

1-percent annual exceedance probability

2-percent annual exceedance probability

4-percent annual exceedance probability

10-percent annual exceedance probability

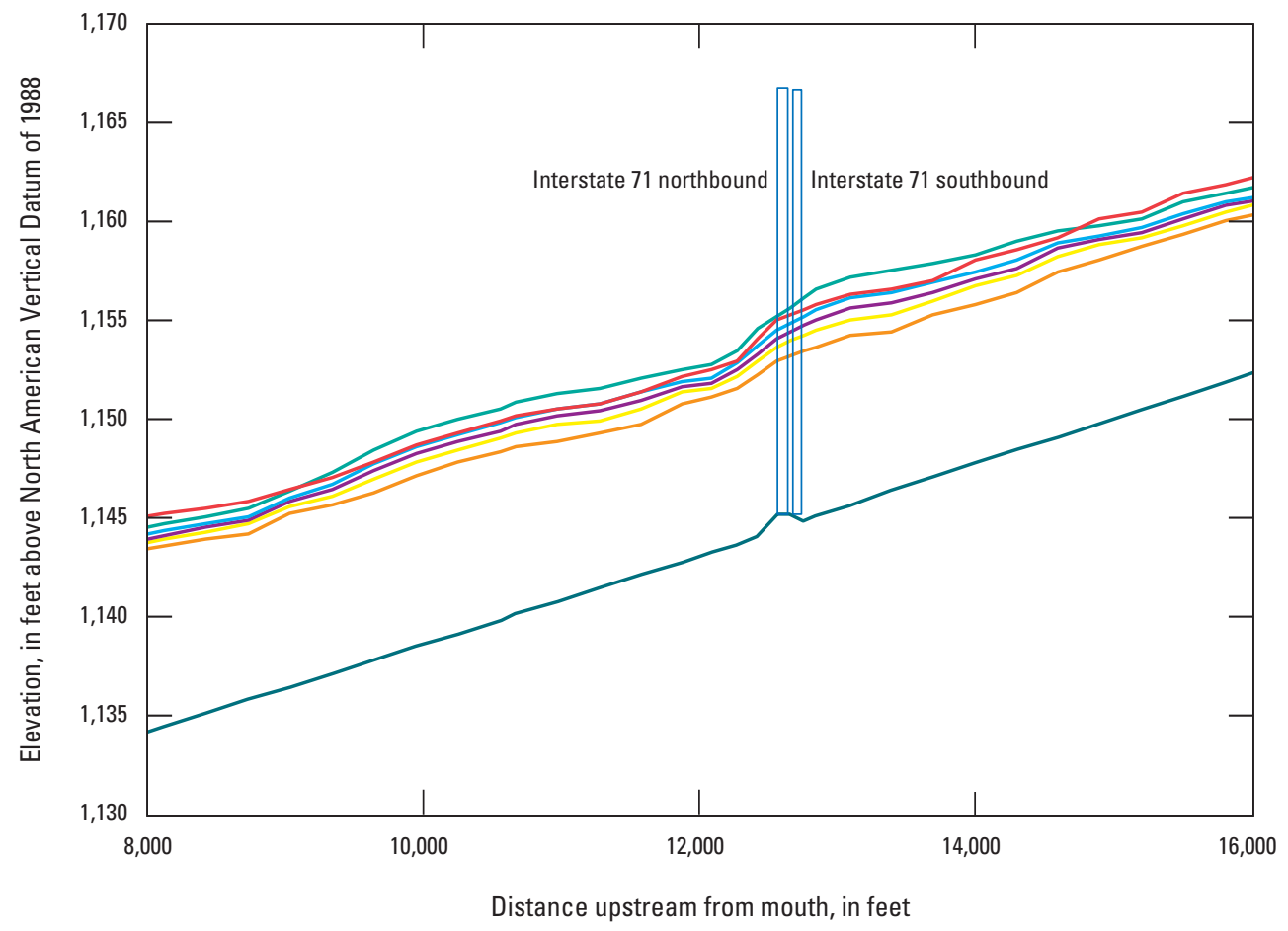

Note: The 1-percent plus flood elevation is defined by Federal Emergency Management Agency (FEMA) as a flood elevation derived by using streamflows that include the average predictive error for the regression equation streamflow calculation for the Flood Risk project. This error is then added to the 1-percent annual exceedance probability flood streamflow to calculate the new 1-percent plus streamflow. In the case of this study, the average predictive error for the 1-percent annual exceedance probability flood is 38 percent. Therefore, the 1-percent plus annual exceedance probability flood streamflows were calculated to be 138 percent of the 1-percent annual exceedance probability flood streamflows.

Figure 1.2. Computed water-surface profiles for flood events with annual exceedance probabilities of 10-, 4-, 2-, 1-, and 0.2-percent and 1-percent plus for the Cedar Fork, Richland County, Ohio. 


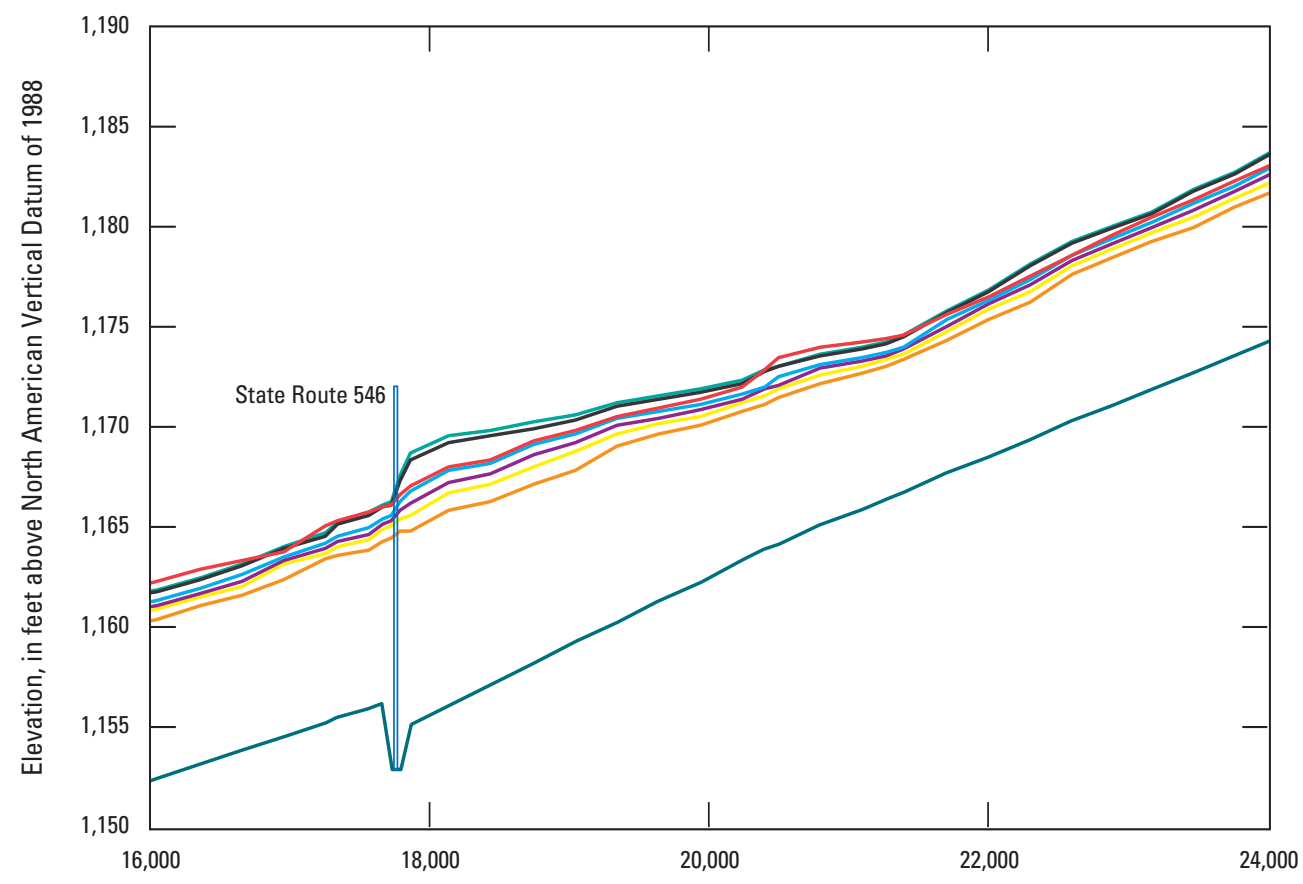

EXPLANATION

Hydraulic structures

0.2-percent annual exceedance probability

1-percent plus annual exceedance probability

Regulatory floodway

1-percent annual exceedance probability

2-percent annual exceedance probability

4-percent annual exceedance probability

10-percent annual exceedance probability

Minimum channel elevation

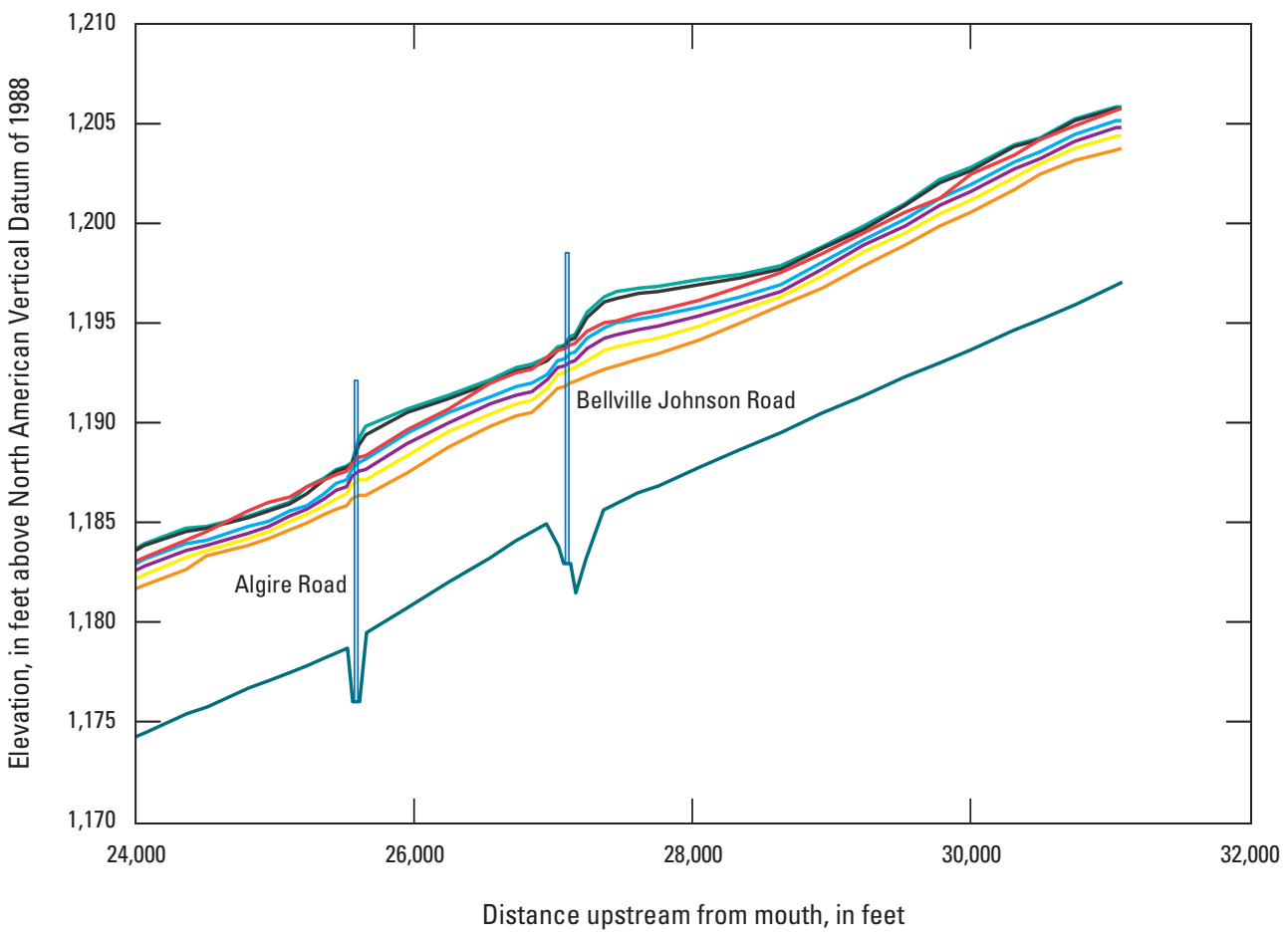

Note: The 1-percent plus flood elevation is defined by Federal Emergency Management Agency (FEMA) as a flood elevation derived by using streamflows that include the average predictive error for the regression equation streamflow calculation for the Flood Risk project. This error is then added to the 1-percent annual exceedance probability flood streamflow to calculate the new 1-percent plus streamflow. In the case of this study, the average predictive error for the 1-percent annual exceedance probability flood is 38 percent. Therefore, the 1-percent plus annual exceedance probability flood streamflows were calculated to be 138 percent of the 1-percent annual exceedance probability flood streamflows.

Figure 1.2. Computed water-surface profiles for flood events with annual exceedance probabilities of 10-, 4-, 2-, 1-, and 0.2-percent and 1-percent plus for the Cedar Fork, Richland County, Ohio.-Continued 


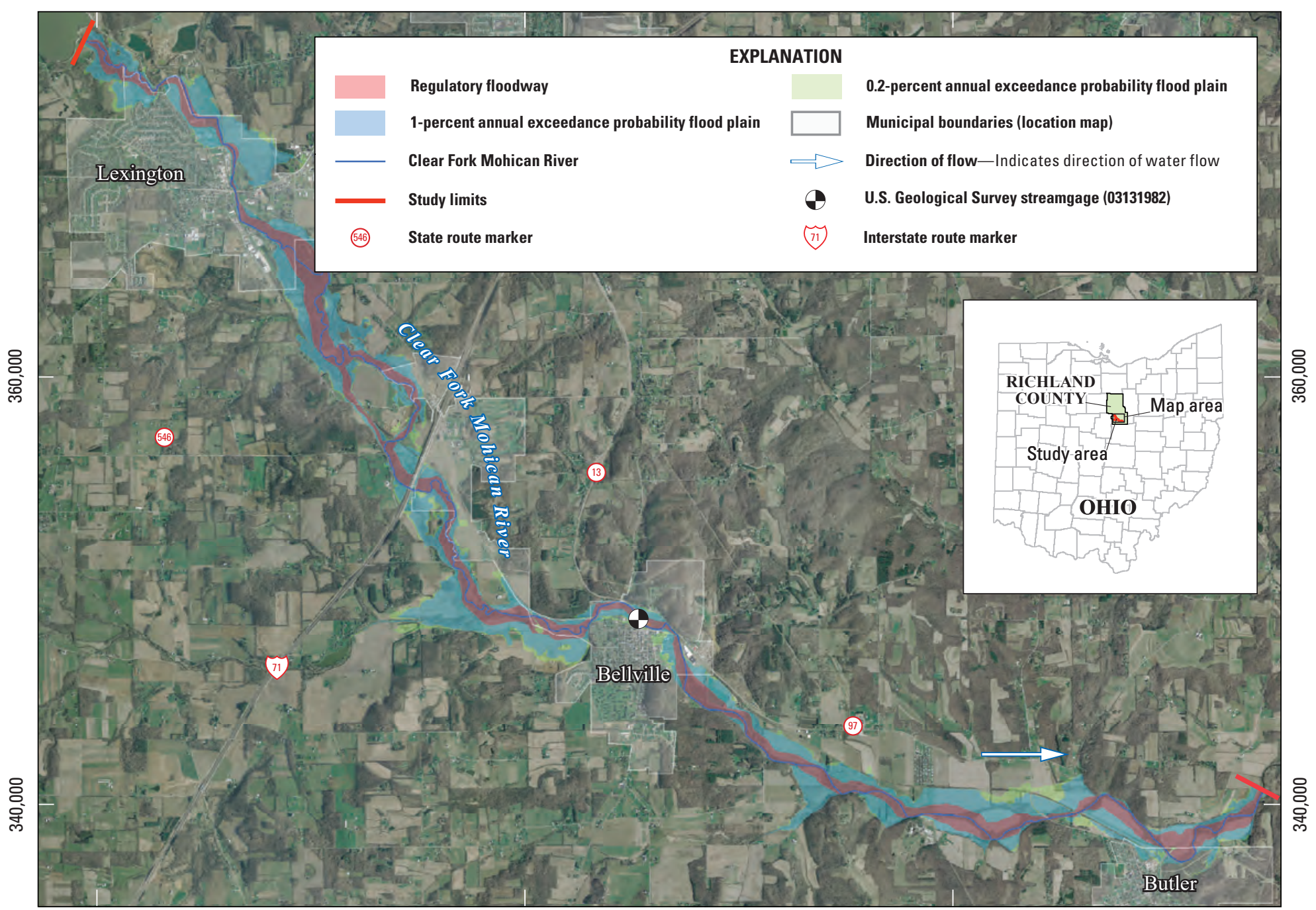

$1,980,000$

Base from U.S. Geological Survey digital data, variously scaled, 2007

Orthophotography from Ohio Geographically Referenced Information Program, 2007

State Plane projection (feet), Ohio North

Horizontal coordinate information is referenced to the North American Datum of 1983 (NAD 83)

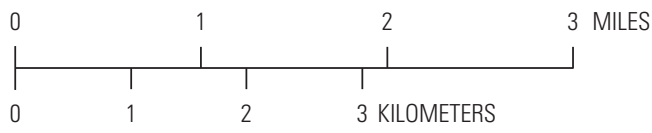

Figure 2.1. Flood inundation areas for the 1- and 0.2-percent annual exceedance probability floods and a regulatory floodway along the Clear Fork Mohican River, Richland County, Ohio. 


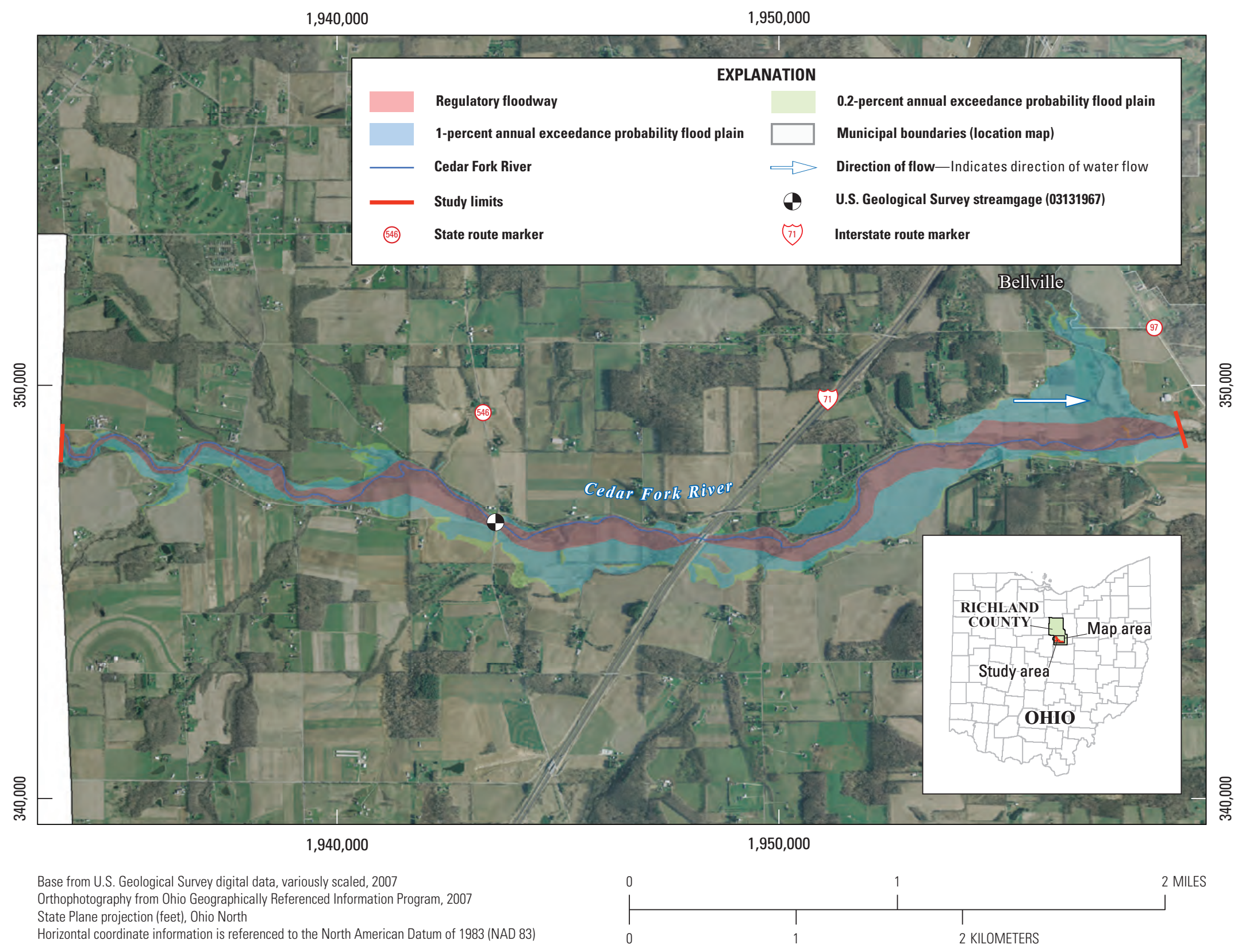

Figure 2.2. Flood inundation areas for the 1- and 0.2-percent annual exceedance probability floods and a regulatory floodway along the Cedar Fork, Richland County, Ohio. 
For more information about this publication, contact

Director, Ohio-Kentucky-Indiana Water Science Center U.S. Geological Survey

6460 Busch Boulevard Suite 100

Columbus, $0 \mathrm{H}$ 43229-1737

614-430-7700

For additional information visit

https://www.usgs.gov/centers/oki-water

Publishing support provided by

Madison Publishing Service Center 

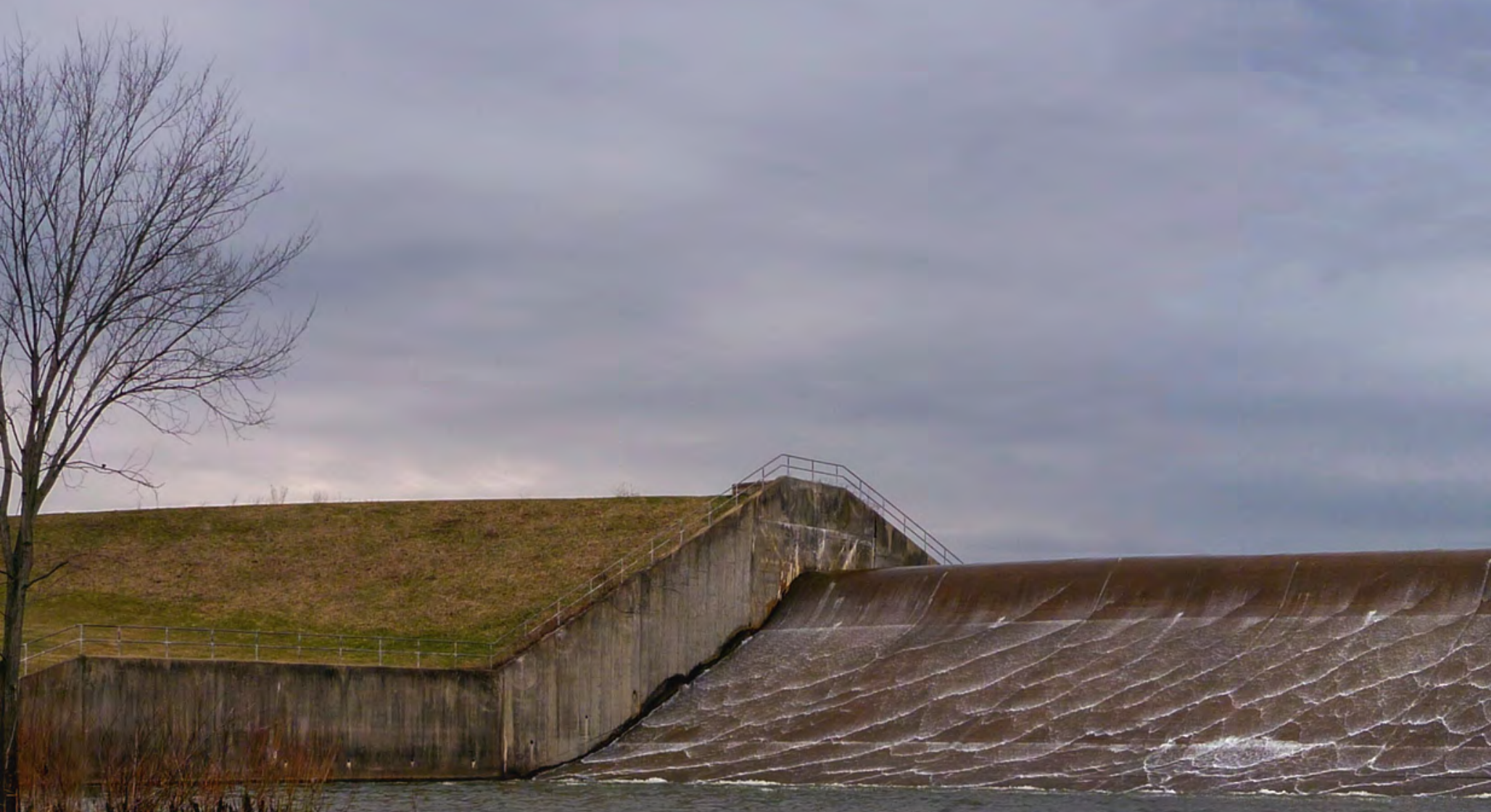

4. 